\title{
棒鋼ダンパーを用いた RC 造方立壁の有効活用に関する実験研究 EXPERIMENTAL STUDY ON THE EFFECTIVE USE OF LIGHTLY RC WALL PIERS UTILIZING STEEL ROD DAMPERS
}

\author{
毎田悠承*1, 森 貴 禎 ${ }^{* 2}$, 坂田弘安*3, 和泉信 之*4, 前川利 雄 ${ }^{* 5}$ \\ Yusuke MAIDA, Takayoshi MORI, Hiroyasu SAKATA, \\ Nobuyuki IZUMI and Toshio MAEGAWA
}

\begin{abstract}
The steel rod damper rationally applied to the lightly $\mathrm{RC}$ wall piers was used, and component tests of the lightly $\mathrm{RC}$ wall piers and subassemblage tests of the $\mathrm{RC}$ frame with lightly $\mathrm{RC}$ wall piers were conducted. The parameters for the subassemblage test specimens were different methods of fixing the steel rod damper to the lightly $\mathrm{RC}$ wall piers. The test results of both specimens show that steel rod dampers start to dissipate energy at an early stage with story drift ratios much smaller than those at yielding $\mathrm{RC}$ frames.
\end{abstract}

Keywords: lightly $R C$ wall piers, steel rod damper, damage control, equivalent viscous damping factor $\mathrm{RC}$ 造方立壁，棒鋼ダンパー，損傷制御，等価粘性減衰定数

\section{1. 序}

近年の地震被害調查から鉄筋コンクリート（以下， RC）骨組にお ける非構造壁の損傷被害が報告されている ${ }^{1)}$ 。非構造壁の損傷抑制 方法として, 構造スリットにより柱梁架構から切り離す方法が挙げ られるが，ラーメン骨組の勒性能に過度に期待して設計した構造物 は, 大地震時に塑性変形が生じ, 残留変形によって継続使用が難し くなる。一方，これまで非構造壁として扱われてきた袖壁などを， 柱梁架構と一体にすることで構造抵抗要素として扱い, 建物の強度 を増加させる検討も近年行われている ${ }^{2)}$ 。 RC 骨組に剛接された非構 造壁は, 小変形域で耐力を発揮した後に脆性破壊し, 継続使用が困 難になる。建物全体の耐力向上およびエネルギ吸収能力確保という 観点からは, 構造スリットを設置することが必ずしも得策とは言え ないのが現状である。

以上のような背景から, 本研究では, 非構造壁である方立壁に着 目し，方立壁へのダンパーの設置による損傷制御構造を提案する。 方立壁の構造スリット部にダンパーを設置することで，ダンパーを 小変形域から降伏させ，方立壁の損傷を抑制できるとともに，建物 全体に耐力, 剛性, および減衰を付与でき, 同じ地震動入力を受け た際には，方立壁に構造スリットを設置した場合よりも，ダンパー を設置した方が応答層間変形角が小さくなり, 柱梁架構の損傷も抑 えられる可能性がある。田口ら ${ }^{3)}$ は RC 造 2 次壁内にアンボンドの
鋼板を X 型に配置し，制振機能を持たせる工法を提案している。塩 原 ${ }^{4)}$ は，プレキャスト（以下，PCa）壁と柱梁架構をダウエル鉄筋 により接合することで，エネルギ吸収能力付与の有効性を示してい る。楠原ら ${ }^{5)}$ は PCa 壁接合部を利用した履歴型ダンパーの開発を, 菅原ら ${ }^{6)}$ は RC 造 2 次壁用の履歴型ダンパーの開発を試みている。 角・吉岡ら ${ }^{7)}$ は，摩擦ダンパーを用いた $\mathrm{RC}$ 造方立壁の制振化に関 する研究を行っている。これらのように， RC 造の非構造壁を耐震 要素, 制振要素として活用しようとする研究はいくつか報告されて おり，より簡易で合理的な方立壁の有効活用法への注目度は高い。 本研究では, RC 造方立壁を構造要素として有効活用するために 方立壁にダンパーを設置した RC 骨組，および方立壁，ダンパー， 方立壁とダンパーの接合部の力学挙動を解明することを目的とする。 その第一段階として，筆者ら ${ }^{8)}$ は鋼製スリットダンパーを設置した

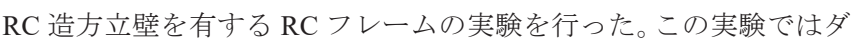
ンパーからの入力せん断力を考慮して設計した方立壁にダンパーを 設置することで柱梁架構と方立壁に悪影響を及ぼすことなく，減衰 効果を付与でき, 本研究で提案するシステムの有効性を示した。一 方，方立壁へのダンパーの接合方法は，方立壁に頭付スタッドを溶 接した鋼板を埋め込む方法としたが，ダンパー接合部の損傷，方立 壁に生じる軸力の影響などによりダンパーの負担せん断力が安定し なかった。本論文では，それらの問題を解決するために，方立壁に

\footnotetext{
*1 国土交通省国土技術政策総合研究所建築研究部 研究官 · 博士 (工学)

*2 元 東京工業大学大学院修士課程 大学院生 - 修士 (工学

*3 東京工業大学環境・社会理工学院建築学系 教授. 工博

*4 千葉大学大学院工学研究院 教授. 博士 (工学)

*5 熊谷組技術本部 工修
}

Researcher, Building Dept., National Institute for Land and Infrastructure Management, MLIT, Dr.Eng.

Former Grad. Student, Tokyo Institute of Technology, M.Eng.

Prof., Dept. of Arch. and Build. Eng., Tokyo Institute of Technology, Dr.Eng. Prof., Graduate School of Eng., Chiba University, Dr.Eng.

Technical Division, Kumagai Gumi Co., Ltd., M.Eng. 
合理的に設置できる棒鋼ダンパーを用い，方立壁の要素実験および 方立壁を有する RC フレーム実験を行い, その力学挙動を把握する。

\section{2. 棒鋼ダンパーを設置した $\mathrm{RC}$ 造方立壁の要素実験}

既報 ${ }^{8)}$ の架構実験では方立壁におけるダンパー接合部の損傷が顕 著であった。また, 架構実験時にダンパーには軸力が生じ, ダンパ 一単体実験で確認された負担し得るせん断力に達していなかった ${ }^{9}$ 。 本章では, それらの問題を解決するために, 方立壁に合理的に設置 するためのダンパーを用い, 要素実験によりその力学挙動を確認す るとともに, 第 1 折れ点荷重, 最大荷重の評価法の検討を行う。

\section{1 要素実験の概要}

\subsection{1 試験体}

試験体詳細を Fig. 1 に，試験体諸元を Table 1 に，コンクリートの 材料特性を Table 2 に，鉄筋・鋼材の材料特性を Table 3 に示寸。

試験体は，構造スリットにより上下を分離した RC 造の方立壁お よびスタブからなり, 実大の約 1/2 スケールを想定している。構造

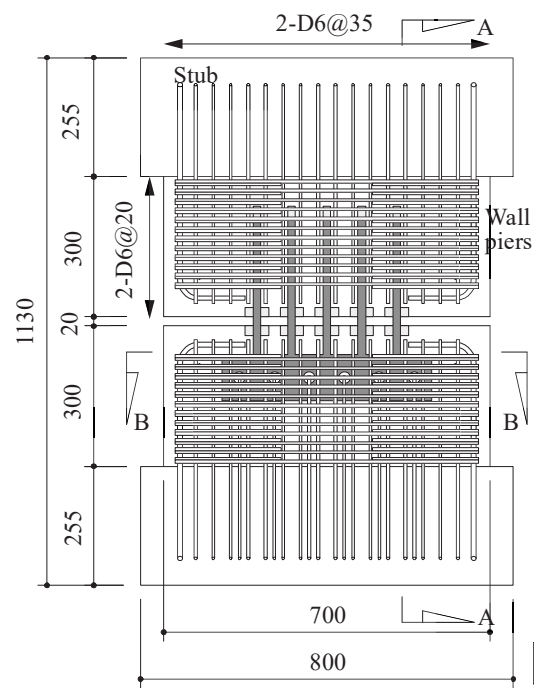

Fig. 1 Specimen

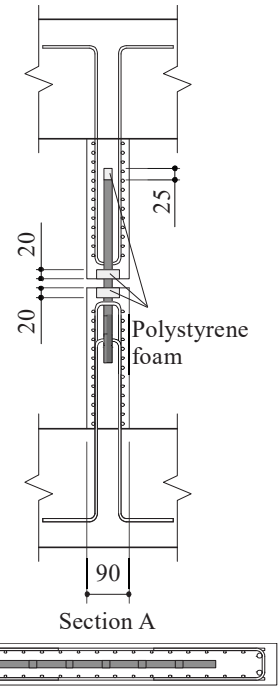

Section B
Table 1 Specimen properties

\begin{tabular}{|c|c|c|c|c|}
\hline Specimen & S16P & S20P & $\mathrm{S} 16 \mathrm{H}$ & D16P \\
\hline$D \times h \times t[\mathrm{~mm}]$ & \multicolumn{4}{|c|}{$700 \times 620 \times 90$} \\
\hline $\begin{array}{c}\text { Longitudinal } \\
\text { rebar }\end{array}$ & \multicolumn{4}{|c|}{ 2-D6@38 (SD295A) } \\
\hline Stirrups & \multicolumn{4}{|c|}{ 2-D6@20 (SD295A) $p_{\mathrm{w}}=3.5 \%$} \\
\hline $\begin{array}{c}\text { Opening } \\
\text { reinforcement }\end{array}$ & \multicolumn{4}{|c|}{ 4-D10 (SD295A) } \\
\hline
\end{tabular}

$D$ :Depth, $h$ :Height, $t:$ Thickness
スリット部に設置するための棒鋼ダンパー部材をパラメータとした 計 4 体の実験を行った。

\subsection{2 棒鋼ダンパー部材と接合方法の詳細}

構造スリット部に設置する棒鋼ダンパー部材，接合方法の詳細を Fig.2 に示寸。基準となる S16P 試験体は，鋼板を Fig.2 (a)に示すよ うな孔あき鋼板ジベル一体型角棒鋼に加工し，方立壁に設置する。 この鋼部材は，方立壁が水平力を受けると角棒鋼の可撓部上下端が 曲げ降伏することによるエネルギ吸収機構に期待したものである。 方立壁に生じる軸力の影響により可撓部の曲げ耐力が低下しないよ うにするため, 上側方立壁に挿入している部分はアンボンド処理を 施すとともに棒鋼上部にポリスチレンフォームを設置し，軸方向非 拘束としている。また，エネルギ吸収部の可撓長さを確保するため に，構造スリット側の上下方立壁縁からそれぞれ $20 \mathrm{~mm}$ ずつの区間 の棒鋼周囲にもポリスチレンフォームを設置した。したがって，構 造スリット幅と上下ポリスチレンフォームによって，可撓長さは $60 \mathrm{~mm}$ となる。

本論文において，棒鋼ダンパー付き方立壁で想定している破壊モ ードは，棒鋼の可撓部端部の曲げ降伏である。また，鋼材ダンパー では繰り返し加力を受けると降伏後も耐力上昇寸るため, それを考 慮したダンパーの最大荷重に対しても, ダンパー周辺部のコンクリ 一トが大きな損傷を受けることなく，ダンパー部が安定した履歴特 性を示すような定着区間の配筋とする。ダンパー周辺の配筋量の決 定方法，および下側方立壁に挿入している孔あき鋼板ジベル部の設 計について述べる。筆者らは，文献 9）において，Fig.3 に示寸鋼製 スリットダンパー単体の水平力載荷実験を行い, ダンパーのせん断 力算定法の検討を行っている。鋼製スリットダンパーは，せん断力 を受けるとスリット間のリブが曲げモーメントを負担し，リブの上 下端部が曲げ降伏することでエネルギ吸収する履歷減衰型ダンパー で, 本論文で用いた棒鋼ダンパーと同じ機構のものである。文献 9) の実験では，鋼製スリットダンパーは，降伏後の繰り返し載荷によ り荷重が徐々に上昇した。この理由として Fig.4 に示すように, 塑 性域の広がりによるものと考察している。また, 文献 10), 11）に
Table 2 Material properties of concrete

\begin{tabular}{c|c|c|c}
\hline & $\begin{array}{c}\sigma_{\mathrm{B}} \\
{\left[\mathrm{N} / \mathrm{mm}^{2}\right]}\end{array}$ & $\begin{array}{c}\sigma_{\mathrm{T}} \\
{\left[\mathrm{N} / \mathrm{mm}^{2}\right]}\end{array}$ & $\begin{array}{c}E_{\mathrm{C}} \\
{\left[\mathrm{N} / \mathrm{mm}^{2}\right]}\end{array}$ \\
\hline \hline S16P & 32.2 & 2.5 & 23400 \\
\hline S20P & 32.4 & 2.5 & 25700 \\
\hline S16H & 32.3 & 2.1 & 23900 \\
\hline D16P & 29.4 & 2.2 & 23100 \\
\hline
\end{tabular}

$\sigma_{\mathrm{T}}$ : Concrete tensile strength, $E_{\mathrm{C}}$ : Concrete elastic modulus

\section{Table 3 Material properties of steel}

\begin{tabular}{c|c|c|c|c}
\hline & $\begin{array}{c}\sigma_{\mathrm{y}} \\
{\left[\mathrm{N} / \mathrm{mm}^{2}\right]}\end{array}$ & $\begin{array}{c}\sigma_{\mathrm{u}} \\
{\left[\mathrm{N} / \mathrm{mm}^{2}\right]}\end{array}$ & $\begin{array}{c}E_{\mathrm{S}} \\
{\left[\mathrm{N} / \mathrm{mm}^{2}\right]}\end{array}$ & $\begin{array}{c}\Delta L / L \\
{[\%]}\end{array}$ \\
\hline $\begin{array}{c}\text { D6 } \\
(\mathrm{SD} 295 \mathrm{~A})\end{array}$ & $423 *$ & 534 & 186000 & 28 \\
\hline $\begin{array}{c}\mathrm{D} 10 \\
(\mathrm{SD} 295 \mathrm{~A})\end{array}$ & 369 & 516 & 194000 & 31 \\
\hline $\begin{array}{c}\text { PL16 } \\
(\mathrm{SN} 400 \mathrm{~B})\end{array}$ & 292 & 461 & 211000 & 45 \\
\hline $\begin{array}{c}\mathrm{D} 16 \\
(\mathrm{SD} 345)\end{array}$ & 392 & 555 & 179000 & 26 \\
\hline
\end{tabular}

$\sigma_{\mathrm{y}}$ : Yield strength, $\sigma_{\mathrm{u}}$ : Tensile strength, Es: Elastic modulus, $\Delta L / L$ : Elongation, $* 0.2 \%$ proof stress

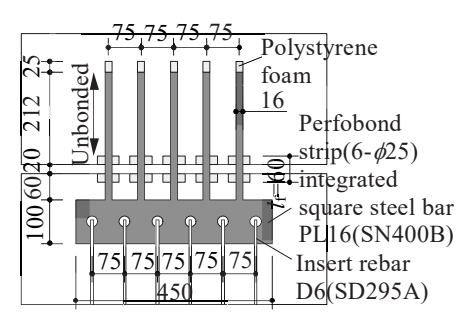

(a) $\mathrm{S} 16 \mathrm{P}$

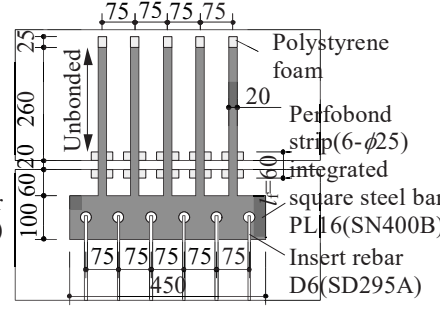

(b) S2OP

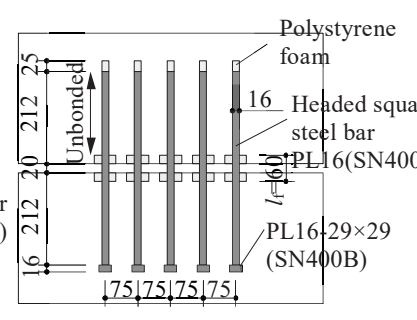

(c) $\mathrm{S} 16 \mathrm{H}$

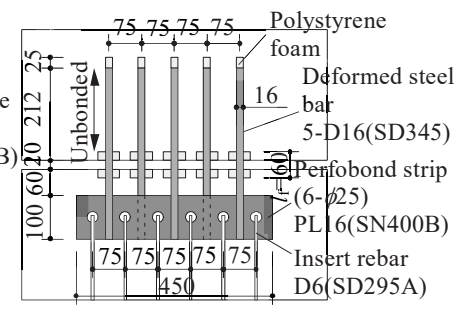

(d) D16P

Fig. 2 Detail of steel damper and connection 


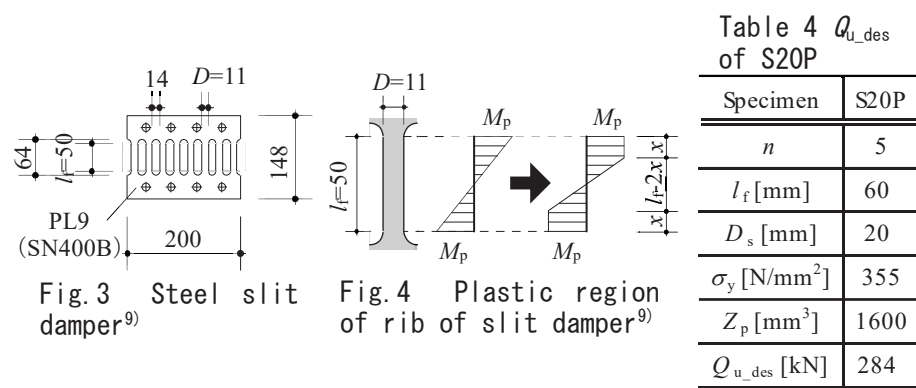

おいても同様に鋼製スリットダンパーの荷重増大が確認されており， 塑性域の広がりや塑性硬化によるものと考察されている。これらを 考慮して, 本論文では, 試験体設計時に用いる棒鋼ダンパーの設計 用最大荷重 $Q_{\mathrm{u} \_d e s}$ は, 十分安全側になる值として, 棒鋼ダンパーの 塑性域が広がる範囲を可撓部上下端からそれぞれ $1.0 D_{\mathrm{s}}\left(D_{\mathrm{s}}\right.$ : 棒鋼の せい，径）区間と仮定して算出されるせん断力計算値とし, 式 (1) により計算した。

$$
Q_{\mathrm{u}_{\mathrm{Cdes}}}=n \cdot 2 M_{\mathrm{p}} /\left(l_{\mathrm{f}}-2 D_{\mathrm{s}}\right)=n \cdot 2 \sigma_{\mathrm{y}} Z_{\mathrm{p}} /\left(l_{\mathrm{f}}-2 D_{\mathrm{s}}\right)
$$

ここで, $n:$ 棒鋼本数 $[$ 本 $], M_{\mathrm{p}}$ : 全塑性モーメント $[\mathrm{Nmm}], l_{\mathrm{f}}$ : 可撓 長さ $[\mathrm{mm}], \quad \sigma_{\mathrm{y}}$ : 鋼材の降伏強度（規格值の最大） $\left[\mathrm{N} / \mathrm{mm}^{2}\right], Z_{\mathrm{p}}$ : 塑 性断面係数 $\left[\mathrm{mm}^{3}\right]$ である。

最も棒鋼の断面が大きい, 後述する S20P 試験体の $Q_{\mathrm{u} \_ \text {des }}$ の計算に 用いた具体的な数值, 計算結果を Table 4 に示す。棒鋼ダンパー周辺 の配筋量はこの $Q_{\mathrm{u} \_d e s}$ に対してせん断破壊しないように決定する。 $Q_{\mathrm{u} \_ \text {des }}$ だけを考慮した場合, 本試験体で用いたほどの高密度配筋とす る必要はないが，履歴ダンパーにおいては，想定外の破壞モードが 生じてはならないため, コンクリートの充填性を考慮した上で可能 な限り配筋できる横筋量とした。また, ダンパーは軸方向非拘束 (片 側頭付き) で且つ十分な定着長を設けているため, ダンパー周辺部 は主にせん断抵抗を考慮する必要があると考え, 主として横筋を高 密度配筋とした。横筋量だけでなく, 縦筋の高密度化や直交拘束筋 の配筋などもパラメータとして, 適切な配筋量を検討する必要があ ると考えており, それらは今後の検討課題とする。孔あき鋼板ジ心゙ ルは $Q_{\text {u_des }}$ に対して文献 12）に基づき設計した。なお，孔あき鋼板 ジベルを用いた試験体では, 全て共通の孔あき鋼板ジベル形状とし た。パラメータは S16P 試験体に対して, 角棒鋼のせい $D_{\mathrm{s}}$ を大きく した S20P 試験体（Fig.2 (b)）, 孔あき鋼板ジベル部を取り除き角棒 鋼に頭を溶接した S16H 試験体（Fig.2 (c)），孔あき鋼板ジベルの表 裏に千鳥に異形棒鋼 D16 を溶接した D16P 試験体（Fig.2 (d)）とし た。S16H の頭部寸法は，頭付きスタッド（JIS B 1198）における軸 径 $16 \mathrm{~mm}$ の頭部直径 $29 \mathrm{~mm}$ を参考に, 頭部径 $29 \mathrm{~mm}$ とした。頭部厚 さは溶接性などを考慮して, JIS 規格の $8 \mathrm{~mm}$ の 2 倍に相当する $16 \mathrm{~mm}$ とした。棒鋼の方立壁への埋め込み長さは $12 D_{\mathrm{s}}$ とし, 最も大きくな る S20P 試験体において, 棒鋼部が試験区間となるようにスタブ間 隔を決定した。以上, 計 4 体の試験体からそれぞれの第 1 折れ点荷 重や最大荷重の計算值と実験值の対応を確認するとともに, 実建物 により合理的に設置できる接合ディテールを検討する。

\subsection{3 第 1 折れ点荷重の計算}

棒鋼ダンパーの第 1 折れ点荷重 $Q_{y_{\text {_cal }}}$ は, 同じ機構である鋼製スリ ットダンパーの第 1 折れ点荷重を概ね評価できている文献 9) 11) の考え方を参考に, ダンパーの可撓部両端が全塑性モーメントに達 した時のせん断力と仮定し，式（2）により計算する。

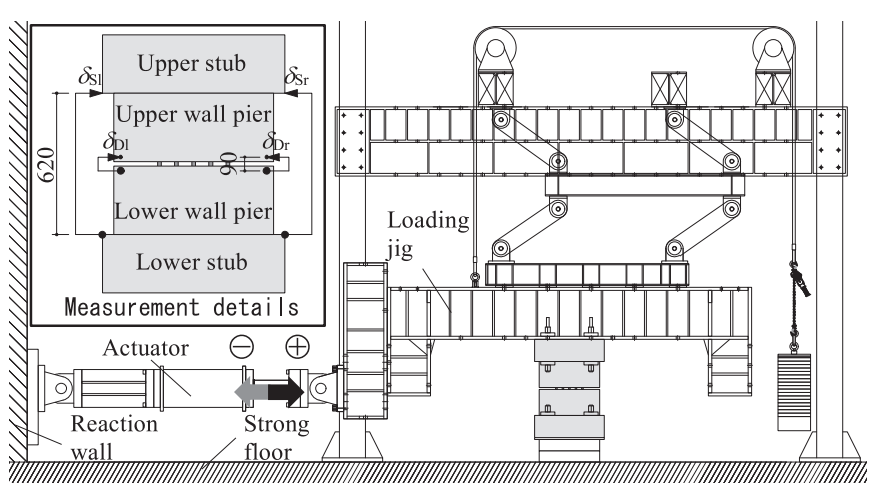

Fig. 5 Test Setup

$$
Q_{\mathrm{y}_{-} \text {cal }}=n Q_{\text {Dy_ } 1_{1}}=n \cdot 2 M_{\mathrm{p}} / l_{\mathrm{f}}=n \cdot 2 \sigma_{\mathrm{y}} Z_{\mathrm{p}} / l_{\mathrm{f}}
$$

ここで, $Q_{\mathrm{Dy} 1}$ : 棒鋼一本当たりの可撓部上下端曲げ降伏時せん断力 $[\mathrm{N}], \sigma_{\mathrm{y}}$ : 鋼材の降伏強度（材料試験結果）[N/ $\left.\mathrm{mm}^{2}\right]$ である。

\section{1.4 載荷 · 計測}

セットアップ・計測詳細を Fig.5 に示す。下側スタブを反力床上 に固定し, コの字形加力治具を介して上側スタブをアクチュエータ に接続し, 試験体中央に水平力を作用させた。実験中は上下スタブ 間の相対水平変位 $\delta_{\mathrm{S}}\left(\delta_{\mathrm{S} 1}\right.$ と $\delta_{\mathrm{Sr}}$ の平均 $)$ を計測し, スタブ間変形角 $R_{\mathrm{S}}\left(=\delta_{\mathrm{S}} / 620 \mathrm{~mm}\right)$ に基づく変位制御とした。目標加力サイクルは $R_{\mathrm{S}}=1 / 800,1 / 400,1 / 200,1 / 100,1 / 50,1 / 33 ， 1 / 25 ， 1 / 20 \mathrm{rad}$ において 正負交番載荷を 2 サイクルずつとした。本加力サイクルは， RC 部 材の変形性能を調べる実験での一般的なものとした。実建物の方立 壁に設置したダンパーにおいては，低降伏点鋼の使用や，多数回繰 り返し加力を受けるなど, この影響は一概には決められないが, 本 加力サイクルによる影響は特別に大きなものではないと考えている。 本実験では，棒鋼と鋼材からなる簡易な部材をダンパーとして方立 壁のような薄い RC 部材に設置した場合の接合ディテールの違いに よる第 1 折れ点荷重や最大荷重の評価, 方立壁の損傷状況などの検 討を主目的としたため，このような簡易な加力サイクルとした。

\section{2 要素実験の結果と考察}

\section{2.1 第 1 折れ点荷重, 最大荷重の評価}

せん断力 $Q$-スタブ間変形角 $R_{\mathrm{S}}$ 関係を Fig.6に示す。図中の○は, 棒鋼全 5 本の可撓部の両端に貼り付けたひずみゲージのいずれかの 計測值が最初に降伏ひずみに到達した点を示している。戝には式(2) により算出した第 1 折れ点荷重計算值 $Q_{\text {y_cal }}$ を破線で示している。ま た, 式 (2) 中の $\sigma_{\mathrm{y}}$ を $\sigma_{\mathrm{u}}($ : 鋼材の引張強度) に代えて算出される荷 重をダンパー最大荷重 $Q_{\mathrm{u} \_ \text {cal }}$ (式 (3) ) として一点鎖線で示す。さら

\begin{tabular}{|c|c|c|c|c|}
\hline Specimen & $\mathrm{S} 16 \mathrm{P}$ & $\mathrm{S} 20 \mathrm{P}$ & $\mathrm{S} 16 \mathrm{H}$ & D16P \\
\hline$n$ & \multicolumn{4}{|c|}{5} \\
\hline$l_{\mathrm{f}}$ (assume value) $[\mathrm{mm}]$ & \multicolumn{4}{|c|}{60} \\
\hline$\sigma_{\mathrm{y}}\left[\mathrm{N} / \mathrm{mm}^{2}\right]$ & \multicolumn{3}{|c|}{292} & 392 \\
\hline$\sigma_{\mathrm{u}}\left[\mathrm{N} / \mathrm{mm}^{2}\right]$ & \multicolumn{3}{|c|}{461} & 555 \\
\hline$Z_{\mathrm{p}}\left[\mathrm{mm}^{3}\right]$ & 1024 & 1600 & 1024 & 683 \\
\hline$Q_{\mathrm{y}_{-} \text {cal }}[\mathrm{kN}]$ & 50 & 78 & 50 & 44 \\
\hline$Q_{\mathrm{u}_{-} \text {cal }}[\mathrm{kN}]$ & 79 & 123 & 79 & 63 \\
\hline$Q_{y_{-} \text {test }}[\mathrm{kN}]$ & 52 & 78 & 51 & 30 \\
\hline$Q_{\mathrm{u}_{\mathrm{L} \text { test }}}[\mathrm{kN}]$ & 79 & 99 & 70 & 52 \\
\hline
\end{tabular}

Table 5 Calculation value, test value 


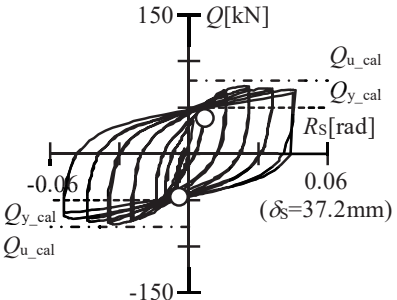

(a) $\mathrm{S} 16 \mathrm{P}$

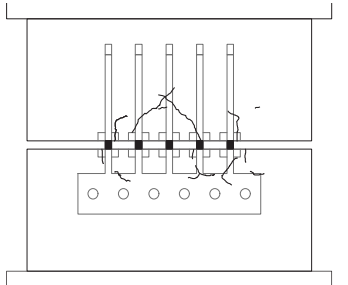

(a) $\mathrm{S} 16 \mathrm{P}$

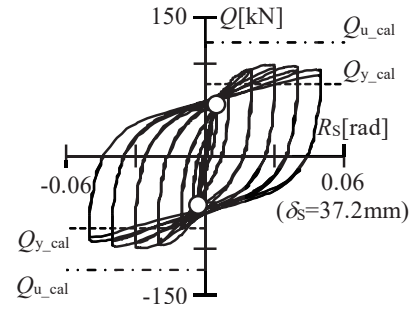

(b) S20P

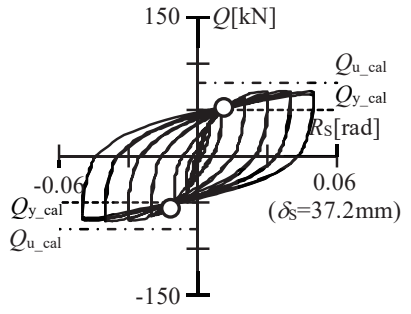

(c) $\mathrm{S} 16 \mathrm{H}$

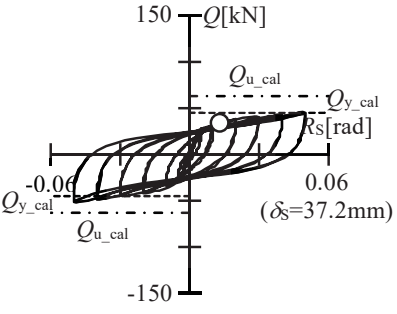

(d) D16P

Fig. 6 Shear force- stub drift ratio relationship of wall pier

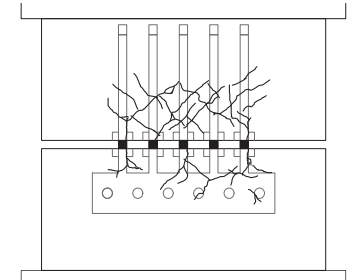

(b) S2OP

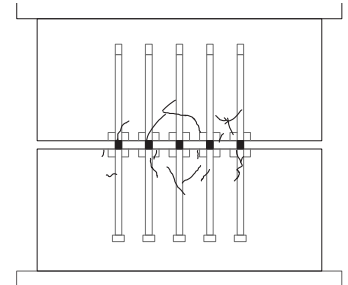

(c) $\mathrm{S} 16 \mathrm{H}$

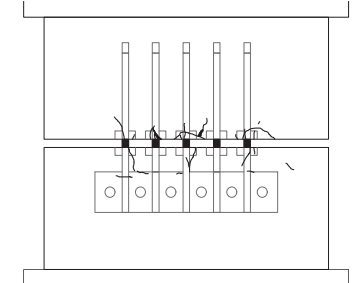

(d) $\mathrm{D} 16 \mathrm{P}$

Fig. 7 Cracks of I ightly RC wall pier at $R_{s}=1 / 50 \mathrm{rad}$

に，それらの計算值，および実験值を Table 5 に示す。

$$
Q_{\mathrm{u}_{-} \text {cal }}=n \cdot 2 \sigma_{\mathrm{u}} Z_{\mathrm{p}} / l_{\mathrm{f}}
$$

いずれの試験体も $R_{\mathrm{S}}=1 / 20 \mathrm{rad}$ まで安定した履歷特性を示した。棒 鋼の可撓部端部が降伏ひずみに到達した点付近から, 荷重一変形関 係においても剛性が低下寸る傾向が確認されたため, その点を第 1 折れ点と定義する。 $Q_{y_{\text {_cal }}}$ は S16P と S16H では第 1 折れ点を良好に 評価できている。ダンパー最大荷重 $Q_{\mathrm{u}}$ は, 式（3）の $Q_{\mathrm{u} \_ \text {cal }}$ により D16P を除く試験体で概ね評価できている。式（3）の $Q_{\text {u_cal }}$ が実験 時のダンパー最大荷重 $Q_{\mathrm{u}}$ であったとした場合に, それに対応する $l_{\mathrm{f}}$ を算定すると, S16P と S16H では 62〜 68mm, S20P では 74〜 75mm, D16P では 73〜82mm である。棒鋼の径や形状, 構造スリット幅な どから一概に評価できないことが分かる。第 1 折れ点以降は繰り返 し載荷により, 棒鋼ダンパーの塑性域の拡大やひずみ硬化が生じ, せん断力が上昇していると考えられ， $l_{\mathrm{f}}$ や耐力上昇率の評価が重要 となるが，現段階ではこれらの定量的評価は難しく，第 1 折れ点荷 重, 最大荷重の評価法については今後の検討課題である。D16P は 中央の鋼板に異形棒鋼を溶接したため, ダンパー部が偏心し, かぶ り厚も小さいため, 想定した塑性化状況になっていないと考えられ, 上述の計算法では第 1 折れ点荷重, 最大荷重を評価できない。また, 棒鋼ダンパーの剛性を, 棒鋼の可撓部が両端固定の逆対称曲げを受 けるものと仮定し, 実験值の評価を試みたが，計算值と実験值に大 きな差異があった。この原因として，可撓部端部のコンクリートの ひび割れの影響により, 境界条件が想定とは異なっていることが考 えられ, 剛性の評価法については今後の課題である。

\subsection{2 ひび割れ性状}

$R_{\mathrm{S}}=-1 / 50 \mathrm{rad}$ 時のひび割れ状況を Fig.7 に示す。 S16P では $R_{\mathrm{S}}=1 / 100 \mathrm{rad}$ 時, $\mathrm{S} 20 \mathrm{P}$ では $R_{\mathrm{S}}=1 / 800 \mathrm{rad}$ 時, $\mathrm{S} 16 \mathrm{H}$ では $R_{\mathrm{S}}=1 / 200 \mathrm{rad}$ 時, $\mathrm{D} 16 \mathrm{P}$ では $R_{\mathrm{S}}=1 / 400 \mathrm{rad}$ 時に構造スリット付近の棒鋼周辺に $0.1 \mathrm{~mm}$ 未満のひび割れが生じた。いずれの試験体も $R_{\mathrm{S}}= \pm 1 / 50 \mathrm{rad} の$ 大変形域までひび割れが顕著に拡がることはなく, 最大でも $0.1 \mathrm{~mm}$ に抑えられていた。方立壁のせん断変形も計測していたが，実験終 了までほとんどゼロであり, スタブ間相対変位 $\delta_{\mathrm{S}}\left(\mathrm{Fig} .5\right.$ 中 $\delta_{\mathrm{Sl}}$ と $\delta_{\mathrm{Sr}}$ の平均) がほぼそのまま棒鋼ダンパーの可撓部の変形 $\delta$ D (Fig. 5 中
$\delta_{\mathrm{Dl}}$ と $\delta_{\mathrm{Dr}}$ の平均）として生じていた。以上のことから, 要素実験を 行った 4 体の試験体では, S16P と S16H が方立壁の損傷が抑えられ たまま, 実験終了まで安定した履歴特性を示し, 第 1 折れ点荷重や 最大荷重の計算值と実験值の対応も良好であった。鋼材の加工や壁 筋の配筋の煩雑さ等を考慮すると, $\mathrm{S} 16 \mathrm{H}$ が実建物に設置する場合, 最も合理的な接合ディテールであると言える。

\section{3. 棒鋼ダンパー付き方立壁を有する RC フレームの実験}

本章では，前章で用いた棒鋼ダンパー付き方立壁を有する $\mathrm{RC}$ フ レームの実験を行い，架構が地震時に水平力を受け，上下層の梁が 曲げ変形することにより，上下の方立壁間に生じる付加水平変位や 軸方向変位などが棒鋼ダンパーや，方立壁に与える影響，およびフ レーム全体の力学挙動に関して検討する。

\section{1 フレーム実験の概要}

\section{1.1 試験体}

試験体形状を Fig.8 に, 試験体のパラメータとなる棒鋼ダンパー の詳細を Fig.9 に示す。また, 試験体諸元を Table 6 に, コンクリー 卜の材料特性を Table 7 に, 鉄筋・ダンパー用鋼材の材料特性を Table 8 に示す。

試験体は $\mathrm{RC}$ の柱・梁および棒鋼ダンパー付き方立壁からなる 1 層 1 スパンの平面フレームである。中層 $\mathrm{RC}$ 造建物を模擬し，実大 の約 $1 / 2$ スケールを想定したものである。柱および梁の断面は，梁 の曲げ降伏を先行させるため, RC 規準 ${ }^{13)}$ の曲げ降伏モーメント略 算式を用いて, 柱梁曲げ降伏耐力比を 3.4 として設計した。柱への 軸力は導入していない。なお，柱・梁の断面，配筋，使用鉄筋の種 別，コンクリートの設計基準強度などは既報 ${ }^{8)}$ で用いた試験体と同 一としたため, 材料の実強度にやや違いはあるものの, 方立壁に構 造スリットを設けて, 振れ止め筋 3-D6(SD295A)のみを配筋したほぼ $\mathrm{RC}$ フレームのみの性状と言える試験体（試験体名「スリット試験 体」 ${ }^{8)}$ ) と比較検討できる。

試験体における構造スリットは方立壁の中央に設け, そこに前章 の要素実験において, 棒鋼ダンパー周辺の損傷が小さく, 履歴特性 も安定し，鋼材の加工や壁筋の配筋がより簡易なディテールであっ 


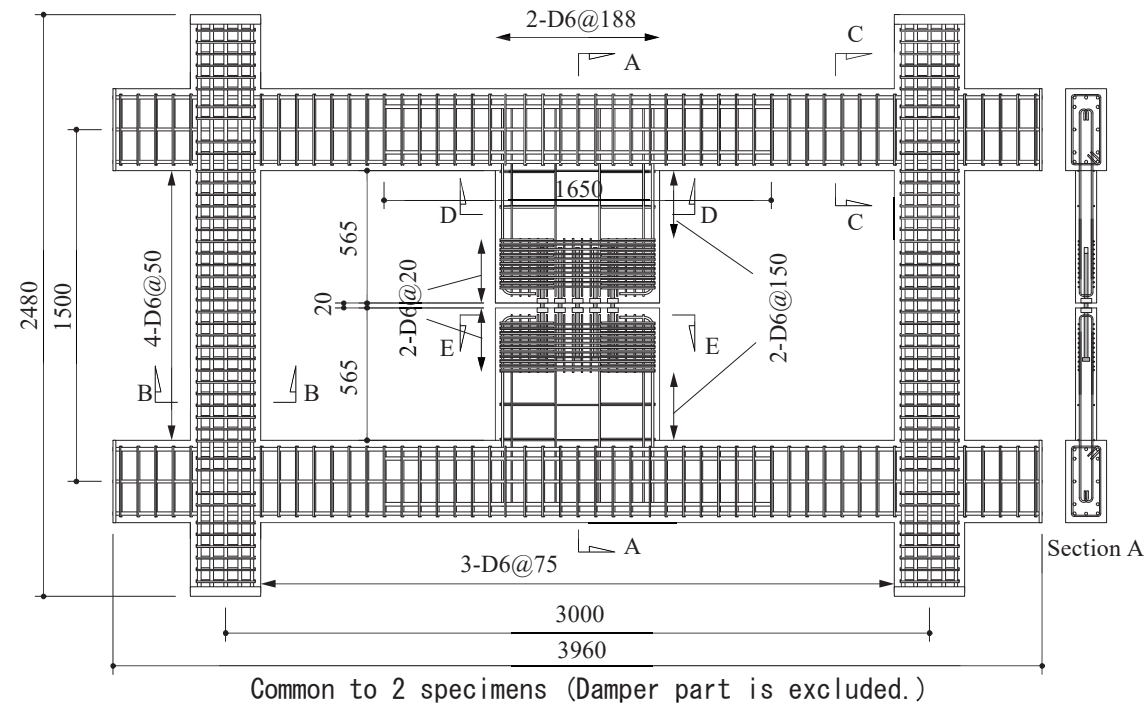

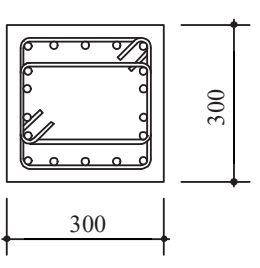

Section B

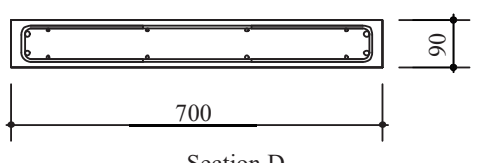

Section D

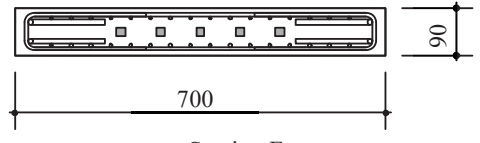

Section E

Fig. 8 Specimen

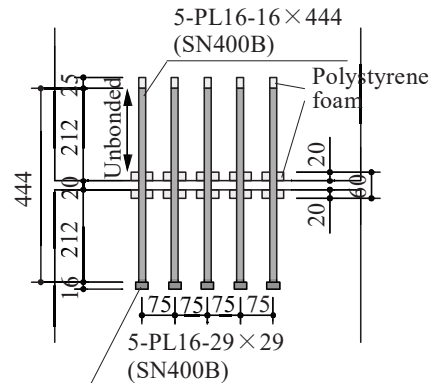

(a) UN

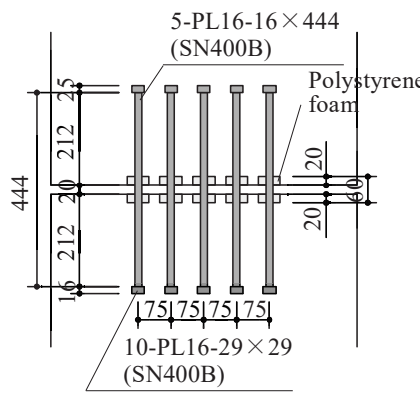

(b) BO

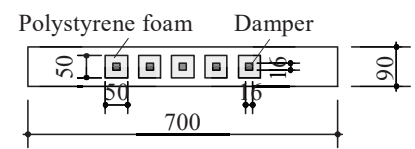

Common to 2 specimens (Section of the damper part) Fig. 9 Parameter details

Table 6 Specimen properties

\begin{tabular}{|c|c|c|c|c|}
\hline \multicolumn{3}{|c|}{ Specimen } & UN & BO \\
\hline \multirow{3}{*}{ Column } & \multicolumn{2}{|c|}{$B \times D[\mathrm{~mm}]$} & \multicolumn{2}{|c|}{$300 \times 300$} \\
\hline & \multicolumn{2}{|c|}{ Longitudinal rebar } & \multicolumn{2}{|c|}{$18-\mathrm{D} 13(\mathrm{SD} 345) p_{\mathrm{g}}=2.54 \%$} \\
\hline & \multicolumn{2}{|c|}{ Hoop } & \multicolumn{2}{|c|}{ 4-D6@50 (SD295A) $p_{\mathrm{w}}=0.85 \%$} \\
\hline \multirow{4}{*}{ Beam } & \multicolumn{2}{|c|}{$B \times D[\mathrm{~mm}]$} & \multicolumn{2}{|c|}{$175 \times 350$} \\
\hline & \multirow{2}{*}{$\begin{array}{l}\text { Longitudinal } \\
\text { rebar }\end{array}$} & Edge & 3-D13 & $0.73 \%$ \\
\hline & & Central & $3+2-D 13$ & $=1.21 \%$ \\
\hline & \multicolumn{2}{|c|}{ Stirrups } & \multicolumn{2}{|c|}{ 3-D6@75 (SD295A) $p_{\mathrm{w}}=0.72 \%$} \\
\hline \multirow{6}{*}{$\begin{array}{l}\text { Lightly RC } \\
\text { wall pier }\end{array}$} & \multicolumn{2}{|c|}{$D \times h \times t[\mathrm{~mm}]$} & \multicolumn{2}{|c|}{$700 \times 1150 \times 90$} \\
\hline & \multicolumn{2}{|c|}{ Longitudinal rebar } & \multicolumn{2}{|c|}{$2-\mathrm{D} 6 @ 150(\mathrm{SD} 295 \mathrm{~A}) p_{\mathrm{w}}=0.47 \%$} \\
\hline & \multicolumn{2}{|c|}{ Stirrups } & \multicolumn{2}{|c|}{ 2-D6@188 (SD295A) $p_{\mathrm{w}}=0.38 \%$} \\
\hline & \multirow{2}{*}{$\begin{array}{l}\text { Around } \\
\text { the damper } \\
\text { connection }\end{array}$} & $\begin{array}{c}\text { Longitudinal } \\
\text { rebar }\end{array}$ & \multicolumn{2}{|c|}{ 2-D6@38 (SD295A) } \\
\hline & & Stirrups & \multicolumn{2}{|c|}{ 2-D6@20 (SD295A) $p_{\mathrm{w}}=3.5 \%$} \\
\hline & \multicolumn{2}{|c|}{ Opening reinforcement } & \multicolumn{2}{|c|}{ 2-D10 (SD295A) } \\
\hline
\end{tabular}

$B:$ Breadth, $D:$ Depth, $h:$ Height, $t:$ Thickness

た角棒鋼に頭を溶接した $\mathrm{S} 16 \mathrm{H}$ 試験体と同一の棒鋼ダンパーを設置 した。棒鋼ダンパー付き方立壁の断面については, ダンパー接合部 周辺は前章の要素実験試験体と同一の高密度配筋としている。ダン パーから離れた部分の方立壁の配筋は, 前章の要素実験の $\mathrm{S} 16 \mathrm{H}$ 試 験体で確認されたダンパーの最大荷重（約 $70 \mathrm{kN} ） に$ 対して，曲げ，

Table 7 Material properties of concrete

\begin{tabular}{c|c|c|c}
$\searrow$ & $\begin{array}{c}\sigma_{\mathrm{B}} \\
{\left[\mathrm{N} / \mathrm{mm}^{2}\right]}\end{array}$ & $\begin{array}{c}\sigma_{\mathrm{T}} \\
{\left[\mathrm{N} / \mathrm{mm}^{2}\right]}\end{array}$ & $\begin{array}{c}E_{\mathrm{C}} \\
{\left[\mathrm{N} / \mathrm{mm}^{2}\right]}\end{array}$ \\
\hline \hline $\mathrm{UN}$ & 44.8 & 2.6 & 30500 \\
\hline BO & 41.4 & 2.5 & 29900 \\
\hline
\end{tabular}

BB: Concrete compressive strength, $\sigma_{\Gamma}$ : Concrete tensile strength, $E_{\mathrm{C}}$ : Concrete elastic modulus

Table 8 Material properties of steel

\begin{tabular}{c|c|c|c|c}
\hline & $\begin{array}{c}\sigma_{\mathrm{y}} \\
{\left[\mathrm{N} / \mathrm{mm}^{2}\right]}\end{array}$ & $\begin{array}{c}\sigma_{\mathrm{u}} \\
{\left[\mathrm{N} / \mathrm{mm}^{2}\right]}\end{array}$ & $\begin{array}{c}E_{\mathrm{S}} \\
{\left[\mathrm{N} / \mathrm{mm}^{2}\right]}\end{array}$ & $\begin{array}{c}\Delta L / L \\
{[\%]}\end{array}$ \\
\hline $\begin{array}{c}\text { D6 } \\
(\mathrm{SD} 295 \mathrm{~A})\end{array}$ & $351^{*}$ & 538 & 192000 & 36 \\
\hline $\begin{array}{c}\mathrm{D} 10 \\
(\mathrm{SD} 295 \mathrm{~A})\end{array}$ & 360 & 492 & 192000 & 34 \\
\hline $\begin{array}{c}\text { D13 } \\
(\mathrm{SD} 345)\end{array}$ & $383^{*}$ & 591 & 191000 & 29 \\
\hline $\begin{array}{c}\text { PL16 } \\
(\mathrm{SN} 400 \mathrm{~B})\end{array}$ & 298 & 458 & 205000 & 47 \\
\hline
\end{tabular}

$\sigma_{\mathrm{y}}$ : Yield strength, $\sigma_{\mathrm{u}}$ : Tensile strength, $E_{\mathrm{S}}$ : Elastic modulus, $\Delta L / L$ : Elongation, $* 0.2 \%$ proof stress

およびせん断で破壊しないよう設計した。なお，方立壁の曲げ耐力 ${ }_{w} M_{\mathrm{u}}$ は構造関係技術基準解説書 ${ }^{14)}$ の略算式（式 (4)), せん断耐力 ${ }_{\mathrm{w}} Q_{\mathrm{su}}$ は文献 14）の広沢 mean 式（式（5））を用いて計算した。

$$
{ }_{\mathrm{w}} M_{\mathrm{u}}=a_{\mathrm{t}} \sigma_{\mathrm{y}} l_{\mathrm{w}}+0.5 a_{\mathrm{w}} \sigma_{\mathrm{wy}} l_{\mathrm{w}}+0.5 N l_{\mathrm{w}}
$$

ここで, $a_{\mathrm{t}}$ : 引張側柱の主筋断面積 $\left[\mathrm{mm}^{2}\right], \sigma_{\mathrm{y}}$ : 引張側柱の主筋の降 伏強度 $\left[\mathrm{N} / \mathrm{mm}^{2}\right], \quad l_{\mathrm{w}}: 0.9 l$ ( $l$ : 壁の全長) $[\mathrm{mm}], a_{\mathrm{w}}$ : 壁の縦筋の断面 積 $\left[\mathrm{mm}^{2}\right], \sigma_{\mathrm{wy}}$ : 壁の縦筋の降伏強度 $\left[\mathrm{N} / \mathrm{mm}^{2}\right], N$ : 壁の軸力 $[\mathrm{N}]$ である。

$$
{ }_{\mathrm{w}} Q_{\mathrm{su}}=\left\{\frac{0.068 p_{\mathrm{te}}^{0.23}\left(\sigma_{B}+18\right)}{\sqrt{\frac{M}{Q D}+0.12}}+0.85 \sqrt{p_{\mathrm{wh}} \cdot \sigma_{\mathrm{wh}}}+0.1 \sigma_{0}\right\} t_{\mathrm{e}} j
$$

ここで, $p_{\mathrm{te}}$ ：等価引張鉄筋比 $[\%], \sigma_{\mathrm{B}}$ : コンクリートの圧縮強度 [N/mm $\left.{ }^{2}\right], M / Q: h_{0} / 2\left(h_{0}\right.$ : 壁内法高さ) [mm], $D:$ 壁の全せい $[\mathrm{mm}]$, $p_{\mathrm{wh}}$ : 水平せ几断補強筋比 (小数), $\sigma_{\mathrm{wh}}$ : 水平せ几断補強筋の降伏強 度 $\left[\mathrm{N} / \mathrm{mm}^{2}\right], \sigma_{0}$ : 全断面積に対する平均軸方向応力度 $\left[\mathrm{N} / \mathrm{mm}^{2}\right], t_{\mathrm{e}}$ ： 壁厚 $[\mathrm{mm}], j:$ 応力中心距離 $[\mathrm{mm}]$ である。

試験体のパラメータは, 方立壁への棒鋼ダンパーの定着方法の違 いとした。基準となる UN 試験体は, 要素実験試験体で最も容易な ディテール, 且つ安定した履歴特性を示した S16H 試験体とダンパ 一を同様としたものである。Fig.9 (a)に示すように，上側方立壁に挿 入した部分はアンボンド処理を施し, 上部にポリスチレンフォーム 
を設置し, ダンパー軸方向が非拘束となる接合とした。UN 試験体 に対して, Fig.9 (b)に示すように上側方立壁に挿入したダンパーの 上部にも，下部と同一の頭を溶接し，アンボンド処理を施さない定 着方法としたものを $\mathrm{BO}$ 試験体とした。谷ら ${ }^{15)}$ は, 方立壁の伸びを 周辺架構が拘束することで, 軸力比 0.15 相当の圧縮軸力が方立壁に 作用寸ると報告しているが，UN 試験体のようなダンパーの接合デ イテールとすることで，この軸力は作用しないと考えられる。

\subsection{2 載荷 · 計測}

セットアップを Fig.10 に示す。上下層柱をピン支持とした。下層 柱のピン支承は反力床に設置した。加力治具を介して上層柱のピン 支承とアクチュエータを接続し，正負交番繰り返し載荷を行った。 本加力方法では, 梁の軸方向伸びをピンに取り付く柱により拘束す る形式となっている。実際の架構においてはスラブが取り付いてい るなど, この拘束の程度は一概には決められないが, 本加力方法に よる拘束は特別に大きなものではないと考えている。本論文では,

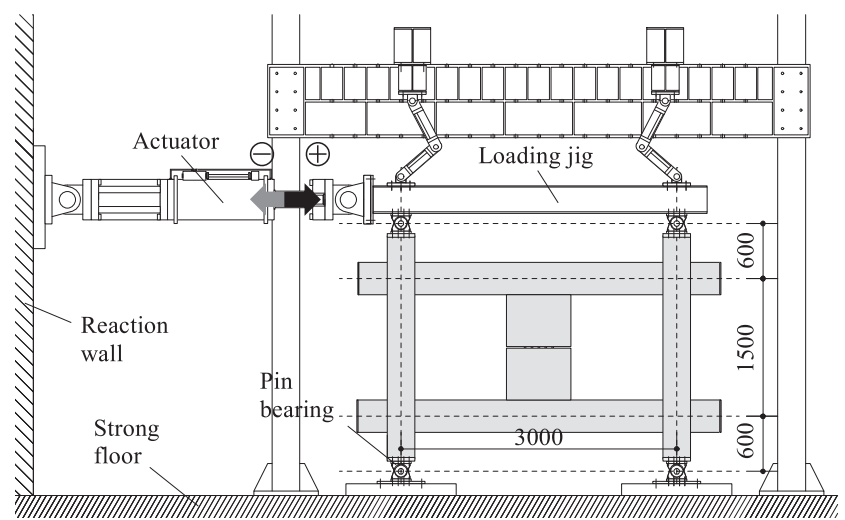

Fig. 10 Test Setup
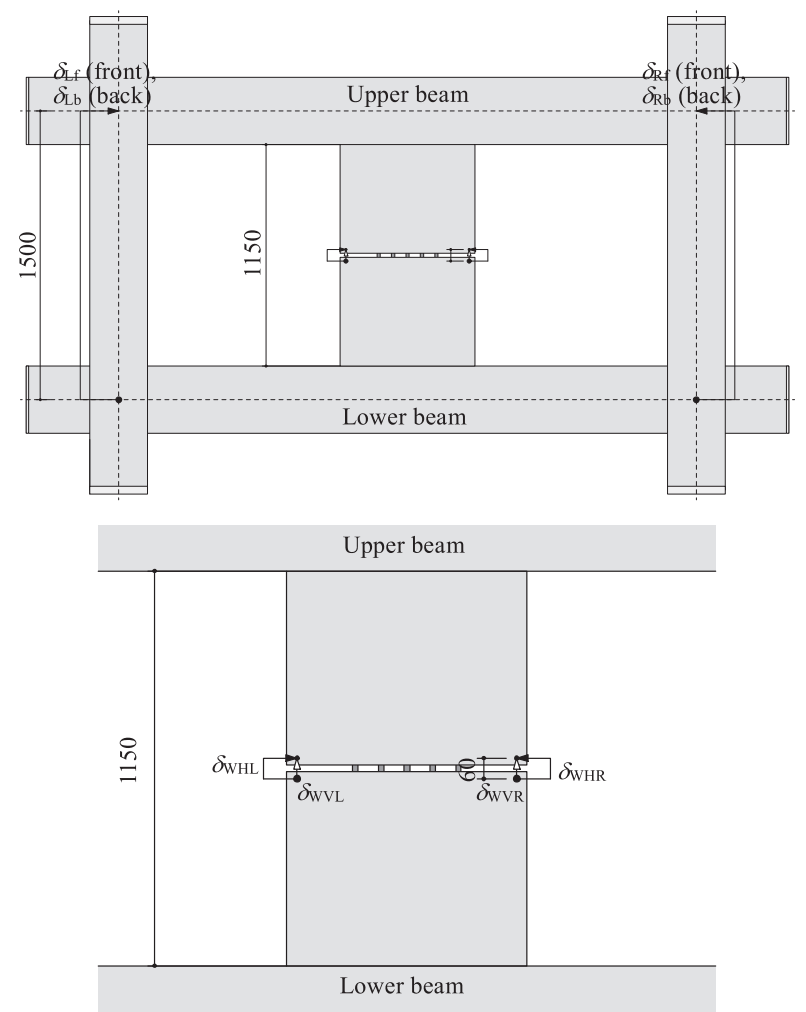

Enlarged figure of the lightly RC wall piers

Fig. 11 Detail of measurement
方立壁へのダンパーの設置による損傷制御効果の検討を主目的とし たため, このような簡易な加力方法とした。目標加力サイクルは層 間変形角 $R=1 / 1600 ， 1 / 800 ， 1 / 400 ， 1 / 200 ， 1 / 100 ， 1 / 67 ， 1 / 50 \mathrm{rad}$ にお いて正負交番載荷を 2 サイクルずつ, $R=1 / 33 \mathrm{rad}$ において正負交番載 荷を 1 サイクル行った後, $R=1 / 25 \mathrm{rad}$ まで正側に載荷し, 除荷して実 験を終了した。上記の加力方法, 加力サイクルは既報 ${ }^{8)}$ のフレーム 実験と同様である。

変位計測の詳細を Fig.11に示す。層間変形は, 左右の柱それぞれ において，下層の柱芯・梁芯の交点と上層の柱芯・梁芯の交点の相 対水平変位を表面と裏面において計測し, その 4 箇所 $\left(\delta_{\mathrm{Rf}}, \delta_{\mathrm{Rb}}, \delta_{\mathrm{Lf}}\right.$, $\left.\delta_{\mathrm{Lb}}\right)$ の平均とした。また，上下方立壁間の相対鉛直変位 $\delta_{\mathrm{WV}}\left(\delta_{\mathrm{WVR}}\right.$ と $\delta_{\mathrm{wVL}}$ の平均）と，上下方立壁間の相対水平変位 $\delta_{\mathrm{WH}}\left(\delta_{\mathrm{wHR}}\right.$ と $\delta_{\mathrm{WHL}}$ の平均）を計測した。なお，前章の要素実験試験体においても，フ レーム実験と同じ計測位置，方法により，上下方立壁間の相対水平 変位（前章では $\delta$ と定義）を計測している。本章のフレーム実験時 にはダンパーが負担するせん断力は計測できないため, フレーム実 験時のダンパーの負担せん断力は, UN 試験体に限ってはフレーム 実験時の $\delta_{\mathrm{WH}}$ が，要素実験 $\mathrm{S} 16 \mathrm{H}$ 試験体の $\delta_{\mathrm{D}}$ と同一の時の荷重にな ると仮定して考察することとする。

\section{2 フレーム実験の結果と考察}

\section{2.1 層せん断カー層間変形角関係}

層せん断力 $Q$ 一層間変形角 $R$ 関係を Fig. 12 に示す。図中には $\mathrm{RC}$ フレームのみの性状とほぼ同等と考えられるスリット試験体 ${ }^{8)}$ の結 果の正側包絡線を破線で併せて示している。スリット試験体では, $R$ が約 $1 / 200 \mathrm{rad}$ 時に梁主筋が降伏し, その時の $Q$ は約 $70 \mathrm{kN}$ であっ た。その後, $R=1 / 100 \mathrm{rad}$ 時に $Q=101 \mathrm{kN}, R=1 / 25 \mathrm{rad}$ 時に最大層せん 断力 $Q_{\max }=125 \mathrm{kN}$ となることが確認されている。また，各試験体の ダンパーの降伏時せん断力計算値 $Q_{\text {Dy_cal }}$, 梁曲げ降伏時の層間変形 角計算值 $R_{\mathrm{Fy} \text { _cal }}$, 梁曲げ降伏時の柱梁架構が負担するせん断力計算 值 $Q_{\text {Fy_cal }}$, 棒鋼ダンパーに貼り付けたひずみゲージの計測值が降伏 ひずみに達した時の層間変形角実験值 $R_{\text {Dy_test }}$, 梁の危険断面位置の 主筋に貼り付けたひずみゲージの計測值が降伏ひずみに達した時の 層間変形角実験值 $R_{\mathrm{Fy} \text { _test }}$ を Table 9 に示す。 $R_{\mathrm{Fy} \_ \text {cal }}$ と $Q_{\mathrm{Fy} \text { _cal }}$ の算出に おいて, 梁の曲げ降伏モーメントは, RC 規準 13) の降伏モーメント 略算式を用いて求め, 降伏時変形は菅野式により算出した。また, 表には UN 試験体のダンパーの最大荷重想定值 $Q_{\text {Du_assum }}$ して, 前 述したように要素実験の S16H 試験体の最大荷重 70kN (鋼材のロッ トは異なるが材料特性はほぼ同じため, 妥当と判断。を示している。 さらに, 梁主筋降伏時の全体の層せん断力実験值 $Q_{\mathrm{Fy} \_ \text {test }}+Q_{\mathrm{D}_{\text {_test }}}$ も併 せて示している。ここで, $Q_{\text {Fy_test }}$ : 梁曲げ降伏時の柱梁架構が負担 するせん断力実験值, $Q_{\text {D_test }}$ : ダンパーの負担せん断力実験值 $\left(Q_{\mathrm{Fy} \_ \text {test }}\right.$ と $Q_{\mathrm{D}_{\mathrm{D} \text { test }}}$ の分離不可）である。

$\mathrm{UN}$ 試験体は $R=1 / 955 \mathrm{rad}$ でダンパーが曲げ降伏し, $R=-1 / 248 \mathrm{rad}$ で 上梁主筋が降伏した。柱，および壁の鉄筋は実験終了まで降伏しな かった。 BO 試験体は, $R=1 / 1053 \mathrm{rad}$ でダンパーが曲げ降伏し, $R=-1 / 296 \mathrm{rad}$ で下梁主筋が降伏した。その後, 方立壁の縦筋, 横筋と もに $R=1 / 40 \mathrm{rad}$ 付近で降伏した。いずれの試験体も $R=1 / 33 \mathrm{rad}$ サイク ルまでは安定した履歴特性を示したが, $\mathrm{BO}$ 試験体では $R=1 / 25 \mathrm{rad} サ$ イクル時に急激な耐力上昇が確認された。これは, BO 試験体では, 上下の方立壁に定着されている棒鋼ダンパーに軸力が発生し, せん 
断荷重のいくらかを軸力によって抵抗する現象，いわゆる「ロープ 効果」 ${ }^{16)}$ が生じたためと考えられる。 UN 試験体は $R=1 / 25 \mathrm{rad}$ 時ま で安定した耐力上昇を続け, その時に $Q_{\max }=180 \mathrm{kN}$ となった。この 層せん断力はスリット試験体の $Q_{\max }=125 \mathrm{kN}$ と前章の $\mathrm{S} 16 \mathrm{H}$ 試験体の 最大せん断荷重 $70 \mathrm{kN}$ の直和には達していないことが分かる。既報 ${ }^{8)}$ のフレーム実験で方立壁に鋼製スリットダンパーを設置した試験体 では大変形域においてダンパー接合部の損傷等によりダンパーが有 効に機能せず耐力低下が生じたが，本論文で用いた軸方向非拘束と した棒鋼ダンパーでは実験終了まで安定した履歴特性を示した。

$R=1 / 100 \mathrm{rad}$ 時における $Q$ は, スリット試験体の約 $101 \mathrm{kN}$ に対し, $\mathrm{UN}$ 試験体では約 $150 \mathrm{kN}$ である。したがって, UN 試験体において 棒鋼ダンパーは約 $49 \mathrm{kN}$ のせん断力を負担していたと仮定する。フ レーム実験の $R=1 / 100 \mathrm{rad}$ 時に, $\mathrm{UN}$ 試験体のダンパー部水平変形は $15 \mathrm{~mm}$ 以上生じていた（3.2.4 に後述）。要素実験の $\mathrm{S} 16 \mathrm{H}$ 試験体はダ ンパー部水平変形が $15 \mathrm{~mm}$ になる時点で既にせん断力は約 $70 \mathrm{kN}$ に 達し, 頭打ちになっていたため, 本来であればフレーム実験の $R=1 / 100 \mathrm{rad}$ 時にダンパーは $70 \mathrm{kN}$ 程度のせん断力を負担していると

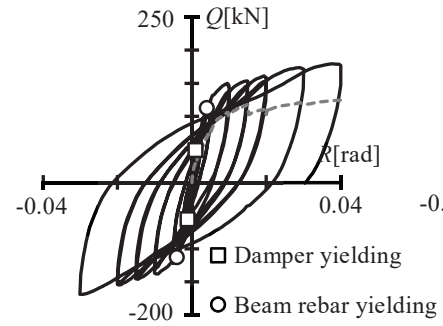

(a) UN

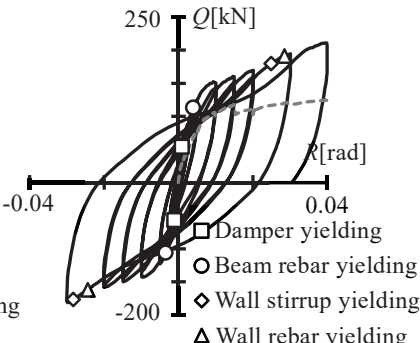

(b) $\mathrm{BO}$
Fig. 12 Shear force- story drift ratio relationship

Table 9 Calculation value, test value

\begin{tabular}{c|c|c}
\hline Specimen & UN & BO \\
\hline \hline$n$ & \multicolumn{2}{|c}{5} \\
\hline$l_{\mathrm{f}}$ (assume value) $[\mathrm{mm}]$ & \multicolumn{2}{|c}{60} \\
\hline$\sigma_{\mathrm{y}}\left[\mathrm{N} / \mathrm{mm}^{2}\right]$ & \multicolumn{2}{|c}{298} \\
\hline$\sigma_{\mathrm{u}}\left[\mathrm{N} / \mathrm{mm}^{2}\right]$ & \multicolumn{2}{|c}{458} \\
\hline$Z_{\mathrm{p}}\left[\mathrm{mm}^{3}\right]$ & \multicolumn{2}{|c}{1024} \\
\hline$Q_{\text {Dy_cal }}[\mathrm{kN}]$ & \multicolumn{2}{|c}{51} \\
\hline$Q_{\text {Du_assum }}[\mathrm{kN}]$ & 70 & - \\
\hline$R_{\text {Fy_cal }}[\mathrm{rad}]$ & \multicolumn{2}{|c}{$1 / 239$} \\
\hline$Q_{\text {Fy_cal }}[\mathrm{kN}]$ & $1 / 955$ & $1 / 1053$ \\
\hline$R_{\text {Dy_test }}[\mathrm{rad}]$ & $1 / 248$ & $1 / 296$ \\
\hline$R_{\text {Fy_test }}[\mathrm{rad}]$ & 113 & 114 \\
\hline $\begin{array}{c}Q_{\text {Fy_test }}+Q_{D_{\text {D_test }}}[\mathrm{kN}] \\
\left(\text { at } R_{\text {Fy_test }}[\mathrm{rad}]\right)\end{array}$ &
\end{tabular}

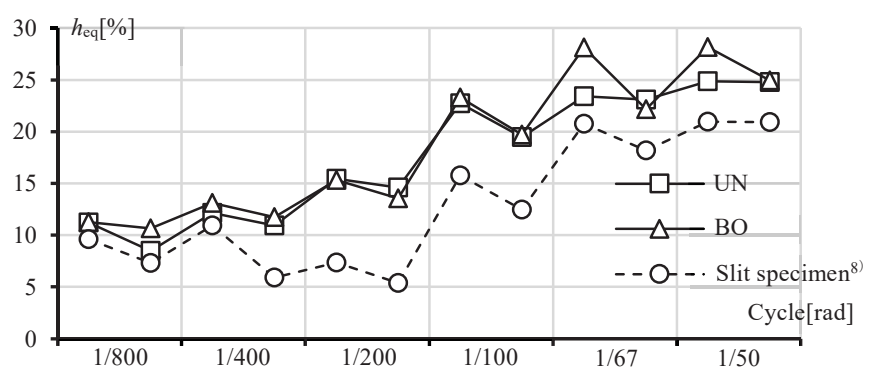

Fig. 13 Equivalent viscous damping factor in each cycle of $1 / 800,1 / 400,1 / 200,1 / 100,1 / 50 \mathrm{rad}$
想定される。しかしながら, 実際には約 $49 \mathrm{kN}$ 程度である。これは, フレーム実験では上下層の梁が曲げ変形することにより, 上下の方 立壁間に付加水平変位や鉛直方向の変位が生じ，要素実験時とはダ ンパーの曲げ降伏位置が変わることで, 可撓長さ $l_{\mathrm{f}}$ 変わり, 負担 するせん断力が小さくなったと考えられる。

\section{2.2 等価粘性減衰定数}

次いで，等価粘性減衰定数 $h_{\mathrm{eq}}$ に着目寸る。各加力イクルにおけ る等価粘性減衰定数 $h_{\mathrm{eq}}$ の推移を Fig. 13 に示す。ほぼ RC フレームの みの性状との比較として, 参考までにスリット試験体 ${ }^{8)}$ の結果も併 せて示している。

$\mathrm{UN}$ 試験体，BO 試験体ともにスリット試験体と比較して, $R=1 / 400 \mathrm{rad}$ の 2 サイクル目から大きな $h_{\mathrm{eq}}$ を示している。 $R=1 / 200 \mathrm{rad}$ および $R=1 / 100 \mathrm{rad}$ サイクルでは，約 7〜 9\%大きくなっており， $\mathrm{RC}$ フレームに減衰性能を付与できることを示した。UN 試験体と BO 試験体を比較すると $R=1 / 100 \mathrm{rad}$ まで，ほぼ同様な $h_{\mathrm{eq}}$ であるが，そ れ以降の大変形域では BO 試験体の方がやや高い $h_{\mathrm{eq}}$ を示した。

\subsection{3 ひび割れ性状}

$R=-1 / 67 \mathrm{rad}$ の 2 サイクル目ピーク時ひび割れ状況を Fig.14に示す。 いずれの試験体も $R=-1 / 800 \mathrm{rad}$ 時に梁端部に曲げひび割れが確認さ れた。 $\mathrm{BO}$ 試験体では, $R=-1 / 100 \mathrm{rad}$ で方立壁に曲げひび割れが生じ, その後の加力で曲げせん断ひび割れに進展した。 $R=-1 / 50 \mathrm{rad}$ でひび 割れが増加した。一方，UN 試験体は $R=-1 / 50 \mathrm{rad}$ で初めて方立壁に 曲げひび割れが生じた。

構造スリット周辺のコンクリート表面の剥離に関しては, UN 試 験体では $R=+1 / 100 \mathrm{rad}$ 加力時に, $\mathrm{BO}$ 試験体では $R=+1 / 67 \mathrm{rad}$ 加力時 に初めて生じた。

$R=+1 / 200 \sim-1 / 50 \mathrm{rad}$ の各加力サイクルのピーク時と除荷時の上層 の梁の最大ひび割れ幅 $w_{\mathrm{BE}}$, および方立壁の最大ひび割れ幅 $w_{\mathrm{WP}}$ の 推移を Fig.15 に示す。構造スリット周辺のコンクリート表面の剥離 は幅の評価ができないため含んでいない。図には耐震性能評価指針 17) に示される損傷度（Damage level I， II，III）の区分を併せて示し ている。文献 17）では, 実構造物における部材の損傷度を評価する 指標としてひび割れ幅の值が示されており, 構造部材 (柱・梁など) では損傷度 I (使用限界) : 残留ひび割れ幅 $0.2 \mathrm{~mm}$ 程度以下, 損傷度 II（修復限界 I）：残留ひび割れ幅は $0.2 \sim 1.0 \mathrm{~mm}$ 程度以下，損傷度 III (修復限界 II)：ひび割れ幅 1〜2mm とされている。非構造部材（方 立壁など）では損傷度 I（使用限界）：残留ひび割れ幅が雨掛かり部 分では $0.1 \mathrm{~mm}$ 以下，損傷度 II（修復限界 I）：残留ひび割れ幅は $1 \mathrm{~mm}$ 程度以下，損傷度 III（修復限界 III）：大きなひび割れが残留とされ ている。本実験の試験体は実大の 1/2 スケールであるため, 文献 17) の指標のひび割れ幅の值をそのまま適用するのは不適切である。試 験体の縮尺がひび割れ幅に与える影響に関して，文献 18）では $1 / 2$ スケールの試験体では，ひび割れ幅も実大の概ね 1/2 になることが 示されている。そのため本論文では，文献 17）に示される指標のひ び割れ幅の值を $1 / 2$ にして評価する。なお，試験体に用いたコンク リートの粗骨材の最大粒径も実構造物に一般的に用いられる 20〜 $25 \mathrm{~mm}$ に対して約 $1 / 2$ の $13 \mathrm{~mm}$ である。ひび割れ幅はクラックスケ

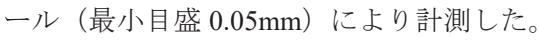

梁の最大ひび割れ幅は，UN 試験体と BO 試験体で明確な差異は 見られない。 $R=-1 / 200 \mathrm{rad}$ 除荷時において, $\mathrm{UN}$ 試験体では損傷度 $\mathrm{I}$ 


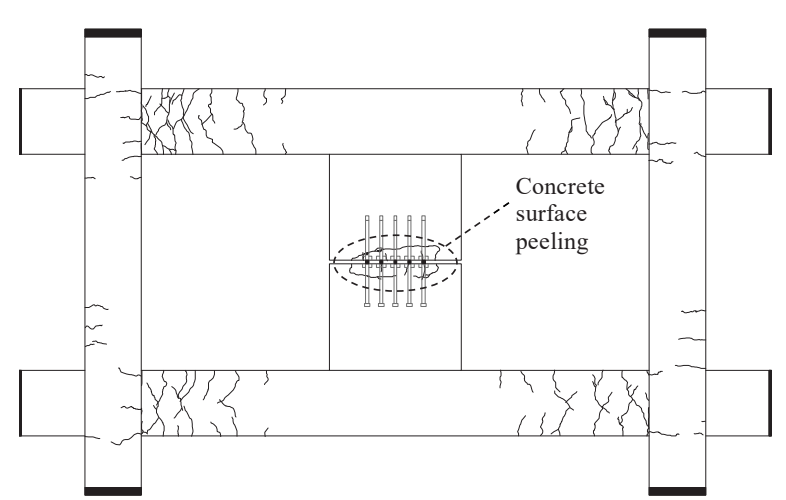

(a) UN

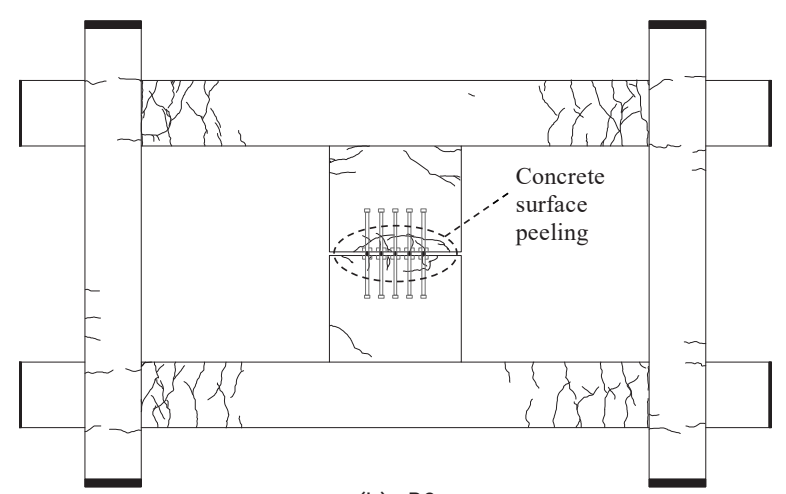

(b) BO

Fig. 14 Cracks of RC frame at $R=1 / 67 \mathrm{rad}$

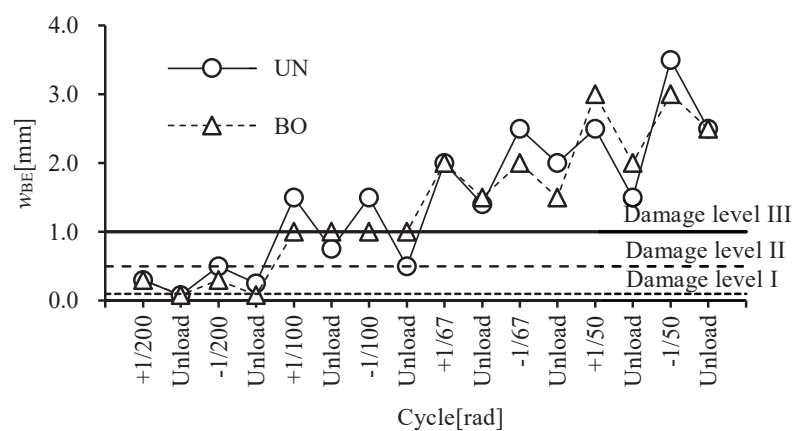

(a) Maximum crack width of upper beam

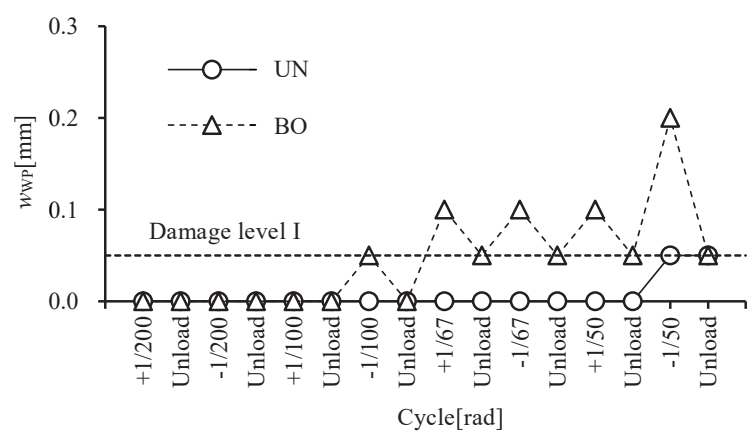

(b) Maximum crack width of wall pier

Fig. 15 Maximum crack width of each member

(使用限界) を超えているが，損傷度 II（修復限界 I）以内には抑 えられえている。方立壁の最大ひび割れ幅に着目すると, $R=1 / 50 \mathrm{rad}$ ピーク時において UN 試験体で $0.05 \mathrm{~mm}, \mathrm{BO}$ 試験体では $0.2 \mathrm{~mm}$ であ った。除荷時の最大残留ひび割れ幅は $\mathrm{BO}$ 試験体では $R=1 / 67 \mathrm{rad}$ か ら損傷度 $\mathrm{I}$ を超えたが, $\mathrm{UN}$ 試験体では $R=-1 / 50 \mathrm{rad}$ まで損傷度 $\mathrm{I}$ を超 えることはなかった。 BO 試験体では, 大変形領域において上下方 立壁には曲げ，およびせん断変形が生じたためと考えられる。UN

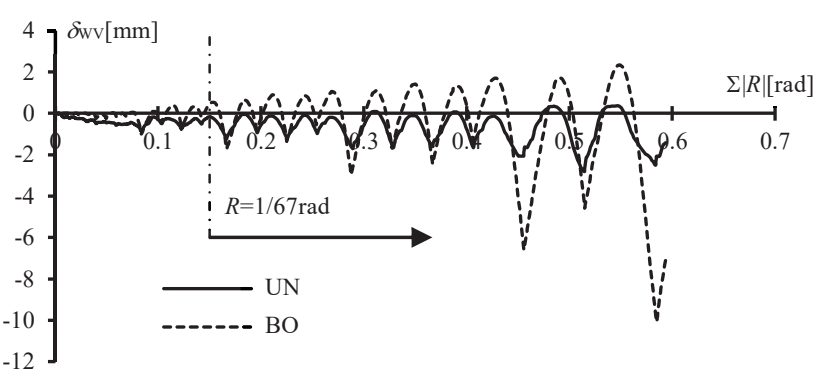

Fig. 16 Relative vertical displacement between upper and lower walls- cumulative story drift ratio relationship
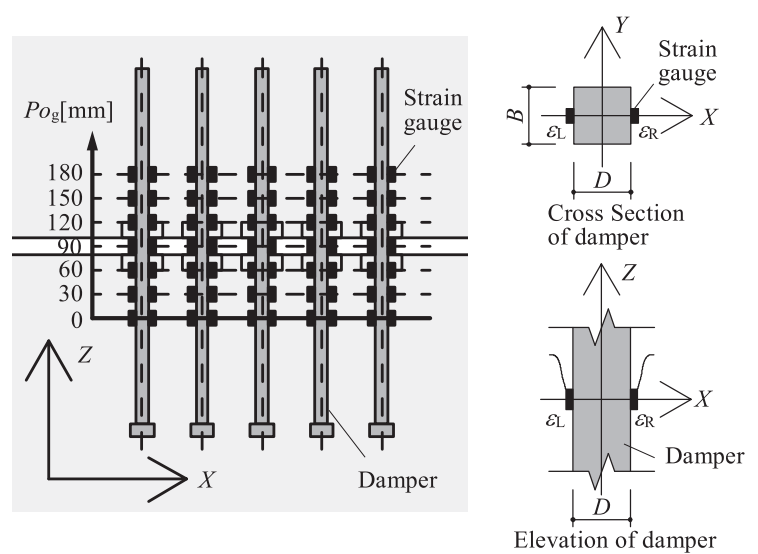

Fig. 17 Strain gauge sticking position of damper

Table 10 Axial strain of steel rod

\begin{tabular}{c|c|c|c|c|c|c|c|c}
\hline & \multicolumn{5}{|c|}{ UN } & \multicolumn{4}{c}{ BO } \\
\hline Cycle $[\mathrm{rad}]$ & $1 / 1600$ & $1 / 800$ & $1 / 400$ & $1 / 200$ & $1 / 1600$ & $1 / 800$ & $1 / 400$ & $1 / 200$ \\
\hline \hline $\begin{array}{c}\varepsilon_{\mathrm{A}}[\mu] \\
(\text { Positive })\end{array}$ & 1 & -6 & -5 & -4 & -153 & -260 & -257 & -303 \\
\hline $\begin{array}{c}\varepsilon_{\mathrm{A}}[\mu] \\
(\text { Negative })\end{array}$ & -1 & -9 & -13 & -30 & 126 & 191 & 238 & 302 \\
\hline
\end{tabular}

試験体では梁主筋が降伏して RC フレームが十分にエネルギ吸収し ている $R=1 / 100 〜 1 / 67 \mathrm{rad}$ 時でも方立壁にはひび割れが生じなかった。

以上のことから, ダンパーからの入力せん断力を考慮して設計し た方立壁に，軸方向非拘束とした棒鋼ダンパーを設置することで， 構造スリット周辺のコンクリート表面に軽微な剥離は生じるものの, $R=1 / 50 \mathrm{rad}$ を超える大変形領域まで方立壁に顕著な損傷を与えるこ となく，減衰効果を付与できることが分かった。

\section{2.4 方立壁の挙動}

\section{【上下方立壁間の相対鉛直変位－累積層間変形角関係】}

上下方立壁間相対鉛直変位 $\delta_{\mathrm{WV}}$ - 累積層間変形角 $\Sigma|R|$ 関係を Fig. 16 に示す。 $\delta_{\mathrm{WV}}$ が正の值は上下方立壁が離れる変位（構造スリット幅 が大きくなる)，負の值は上下方立壁が近づく変位（構造スリット幅 が小さくなる）である。また，棒鋼ダンパーのひずみゲージ貼り付 け位置を Fig. 17 に示す。棒鋼ダンパーの軸ひずみの挙動を検討する ため, 曲げの影響がないと考えられる棒鋼の材軸方向中央位置 $\left(P o_{\mathrm{g}}=90 \mathrm{~mm}\right)$ における $\varepsilon_{\mathrm{R}}$ と $\varepsilon_{\mathrm{L}}$ の平均值を軸ひずみ $\varepsilon_{\mathrm{A}}$ と定義する。 $1 / 1600,1 / 800,1 / 400,1 / 200 \mathrm{rad}$ の 2 サイクル目正負ピーク時の $\varepsilon_{\mathrm{A}}$ を Table 10 に示す。1/100 rad 以降のサイクルではひずみゲージが計測 不能となった。全 5 本のうち最も左の棒鋼の結果を示している。

いずれの試験体も各加力サイクル正負ピーク時に曲線が下に凸と なり，構造スリット幅が小さくなる傾向を示した。これは，ひび割 
れの発生などにより, 方立壁の材長が材軸方向に伸びたためと考え られる。UN 試験体では加力の初期段階から構造スリット幅が小さ くなる挙動を示し, その後, $0.5 \sim-3 \mathrm{~mm}$ 程度の間で推移した。BO 試験体では層間変形が大きくなるにつれて, 構造スリット幅が大き くなる変形と, 小さくなる変形が見られるようになり， $R=1 / 67 \mathrm{rad}$ 以降の変形域で，方立壁の相対鉛直変位の変動が大きくなった。ま た, $R=1 / 33 \mathrm{rad}$ 以降の大変形域では, 正負ピーク時に構造スリット幅 が小さくなる変位が顕著である。軸ひずみに着目すると, UN 試験 体ではほとんど生じていないのに対し，BO 試験体では 1/200rad ピ ーク時で $300 \mu$ 程度生じている。このことから， BO 試験体では棒鋼 ダンパーが上下の方立壁間で軸力を伝達しており, 方立壁にひび割 れが生じることで, 方立壁の材軸方向に伸びが生じ, 大変形域の加 カピーク時には構造スリット幅が小さくなったと考えられる。

\section{【上下方立壁間の相対水平変位一層間変形関係】}

上下方立壁間相対水平変位 $\delta_{\mathrm{WH}}$ 一層間変形 $\delta$ 関係を Fig. 18 に示す。 各加力サイクルピーク時における UN 試験体の方立壁の相対水平変 位は, 層間変形に比べてやや大きくなった。 $R=1 / 400 \mathrm{rad}$ 以降では $15 \%$ 前後, 壁間相対水平変位の方が大きくなっていた。これは前述のよ うに梁の変形による上下方立壁間の水平方向の付加変位の影響であ る。 $\mathrm{BO}$ 試験体は $R=1 / 100 \mathrm{rad}$ までは, $\mathrm{UN}$ 試験体と概ね同様の壁間 相対水平変位を示したが, その後は UN 試験体よりも小さい壁間相 対水平変位が生じており, $R=1 / 25 \mathrm{rad}$ では層間変形より壁間相対水平 変位の方が小さくなった。

\section{2.5 棒鋼ダンパーの挙動}

次いで, 棒鋼ダンパーのひずみから, 棒鋼ダンパーの曲率 $\phi$ を算 出し, その挙動を把握した。曲率は式（6）を用いて算出した。

$$
\emptyset=2\left(\varepsilon_{\mathrm{L}}-\varepsilon_{\mathrm{R}}\right) / D \times 10^{6}
$$

ここで, $\phi:$ 曲率 $[1 / \mathrm{mm}], \varepsilon_{\mathrm{L}}$ : 棒鋼表面ひずみ (左側) $[\mu], \varepsilon_{\mathrm{R}}$ : 棒鋼

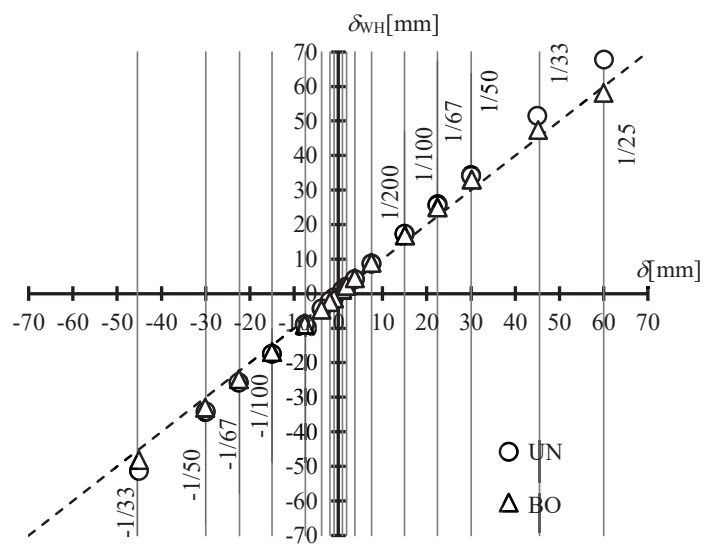

Fig. 18 Relative horizontal displacement between upper and lower walls- story drift relationship

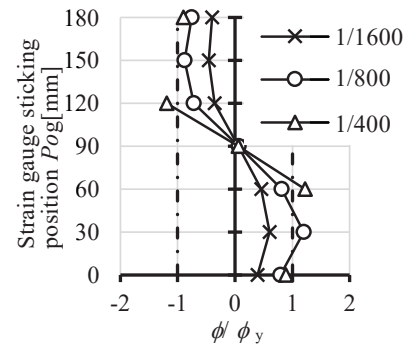

(a) UN

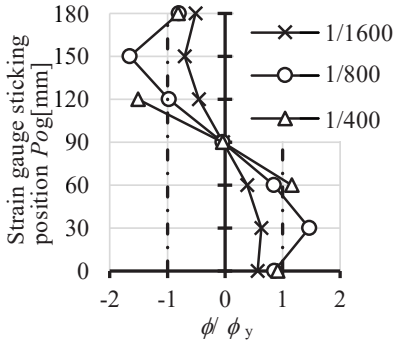

(b) BO
Fig. 19 Curvature distribution of damper
表面ひずみ（右側） $[\mu], D$ : 棒鋼のせい $[\mathrm{mm}]$ である。

また, 棒鋼ダンパー表面が降伏する時の曲率 $\phi_{\mathrm{y}}$ は, 棒鋼ダンパー 部材断面の平面保持を仮定し，式（7）により算出した。

$$
\emptyset_{\mathrm{y}}=M_{\mathrm{y}} / E_{\mathrm{s}} I=\sigma_{\mathrm{y}} Z / E_{\mathrm{s}} I
$$

ここで, $E_{\mathrm{s}}$ : 鋼材のヤング係数 $\left[\mathrm{N} / \mathrm{mm}^{2}\right], I:$ 棒鋼ダンパー 1 本当たり の断面 2 次モーメント $\left[\mathrm{mm}^{4}\right], \sigma_{\mathrm{y}}$ : 鋼材の降伏強度 $\left[\mathrm{N} / \mathrm{mm}^{2}\right], Z$ : 棒 鋼ダンパー 1 本当たりの断面係数 $\left[\mathrm{mm}^{3}\right]$ である。

正側サイクルピーク時における左端の棒鋼ダンパーの曲率の軸方 向分布を Fig.19 に示す。横軸は $\phi$ を $\phi_{\mathrm{y}}$ で除した無次元量で示してい る。 $R=1 / 1600 \mathrm{rad}$ では，両試験体ともに，ひずみを計測したいずれの 箇所も降伏しなかった。 $R=1 / 800 \mathrm{rad}$ では, 両試験体ともに降伏が確 認された。BO 試験体では, 棒鋼ダンパーの上下両側で降伏したが, $\mathrm{UN}$ 試験体では，上側で降伏に至っていなかった。

両試験体の棒鋼ダンパーも, 最も曲率が大きい箇所はコンクリー トの縁ではなく，コンクリート内に上下それぞれ約 $30 \mathrm{~mm}$ 侵入した 位置であった。これは, 式 (2) で想定した可撓域 $60 \mathrm{~mm}$ に対して, 実際には $120 \mathrm{~mm}$ と, 想定の 2 倍になっている。このことからも, 方立壁に設置した棒鋼ダンパーの可撓域, 曲げ降伏時のせん断スパ ンを定量的に評価することは難しく, 棒鋼ダンパーの第 1 折れ点荷 重, 最大荷重の評価式に関しては, 今後も検討を重衫る必要がある。

\section{4. 結}

本論文では RC 造方立壁の有効活用を目的として，方立壁に設置 する合理的な棒鋼ダンパーを用い，方立壁要素実験と，方立壁を有 する RC フレーム実験を行った。以下に得られた結論をまとめる。

1）要素実験では，用いた棒鋼ダンパーは方立壁に顕著な損傷を 与えることなく, 大変形域まで安定した履歴特性を示した。

2）軸方向非拘束として設置した棒鋼ダンパー付き方立壁を有す る $\mathrm{RC}$ フレームでは, ダンパーは $R=1 / 1000 \mathrm{rad}$ 程度の小変形域 で降伏し, $R=1 / 250 \mathrm{rad}$ 程度で降伏する $\mathrm{RC}$ フレームに比べて早 期にエネルギ吸収を開始させられる。また，大変形域におい ても安定した履歴特性を示した。

3）棒鋼ダンパーを上下方立壁に定着した試験体では，大変形域 においてロープ効果により急激な耐力上昇が確認された。ま た，棒鋼ダンパーが上下の方立壁間で軸力を伝達し，方立壁 にひび割れが生じることで, 方立壁の材軸方向に伸びが生じ, 大変形域の加力ピーク時には構造スリット幅が小さくなった。

4）ダンパーからの入力せん断力を考慮して設計した方立壁に, 軸方向非拘束とした棒鋼ダンパーを設置することで，構造ス リット周辺のコンクリート表面に軽微な剥離は生じるものの, $R=1 / 50 \mathrm{rad}$ を超える大変形領域まで方立壁に顕著な損傷を与え ることなく，減衰効果を付与できる。

5）棒鋼ダンパーの最も曲率が大きい箇所は，コンクリートの縁 ではなく，コンクリート内にやや侵入した位置であった。方 立壁に設置した棒鋼ダンパーの可撓域，曲げ降伏時のせん断 スパンを定量的に評価することは難しく, 棒鋼ダンパーの第 1 折れ点荷重, 最大荷重の評価に関して, 今後も検討を重㸚る。

本論文で用いた棒鋼ダンパー付き方立壁を実構造物に適用する際 
は，使用する棒鋼ダンパーに応じたダンパー周辺および方立壁の断 面, 配筋量, その他の保証設計がされることが, この棒鋼ダンパー の性能を確保するための前提条件である。その方法に関して今後も 更なる検討が必要である。

\section{謝辞}

本研究の成果の一部は, (一社) 日本免震構造協会, 2017 年度（第

9 回）「免震構造・制振構造に関わる研究助成」（研究代表者：毎田 悠承）を受け，得られたものです。ここに記して謝意を表します。

\section{参考文献}

1) Joint Editorial Committee for the Report on the Great East Japan Earthquake Disaster: Report on the Great East Japan Earthquake Disaster, Building Series Vol. 1, Reinforced Concrete Buildings, 2015.5 (in Japanese) 東日本大震災合同調査報告書編集委員会: 東日本大震災合同調査報告 建築編 1 鉄筋コンクリート造建築物, 2015.5

2) Toshikazu Kabeyasawa, Tomohisa Mukai, Hiroshi Fukuyama, Hiroto Kato, Haruhiko Suwada, Masaomi Teshigawara, Koichi Kusunoki: A Full Scale Static Loading Test on Five Story Reinforced Concrete Building Utilizing Columns with Wing Walls, Journal of Structural and Construction Engineering (Transactions of AIJ), Vol.81, No.720, pp.313-322, 2016.2 (in Japanese)

壁谷澤寿一, 向井智久, 福山洋, 加藤博人, 諏訪田晴彦, 勅使川原正 臣，楠浩一：袖壁付き柱を活用した実大 5 層鉄筋コンクリート造建築 物の載荷実験, 日本建築学会構造系論文集, 第 81 巻, 第 720 号, pp.313-322, 2016.2

3) Takashi Taguchi, Akira Tasai: Experimental Study on R/C Non-structural Walls with a Role of Vibration Control, Journal of structural engineering, Vol.47B, pp.105-115, 2001.3 (in Japanese)

田口孝，田才晃： RC 造 2 次壁に制震機能を持たせる工法の実験的研究， 構造工学論文集, Vol.47B, pp.105-115, 2001.3

4) Hitoshi Shiohara: Development of Non-structural Jointed Precast Concrete Panel for Earthquake response control, Summaries of Technical Papers of Annual Meeting, Architectural Institute of Japan, C-2, pp.121-124, 2006.9 (in Japanese)

塩原等：制震機能内蔵型のプレキャストコンクリート非構造部材の開 発にむけて, 日本建築学会大会学術講演梗概集, C-2 分冊, pp.121-124, 2006.9

5) Fumio Kusuhara, Hitoshi Shiohara, Kiyoshi Okamura, Taku Ishioka: Development of a Large-Span Precast Concrete Structural System with Ease of Construction using Prestressed Connections Part 6: Development of a Hysteresis Damper Type of Panel Connecter, Summaries of Technical Papers of Annual Meeting, Architectural Institute of Japan, C-2, pp.661-662, 2008.9 (in Japanese)

楠原文雄, 塩原等, 岡村喜吉, 石岡拓: 構造安全性と生産合理性の融 合を目指した鉄筋コンクリート造事務所ビル建築に関する研究：その 6: 履歴型制震デバイスの開発, 日本建築学会大会学術講演梗概集, C-2 分冊, pp.661-662, 2008.9

6) Takayuki Sugawara, Mitsuo Miyazaki: Development of a Slit Damper for Secondary RC-Wall, Summaries of Technical Papers of Annual Meeting, Architectural Institute of Japan, B-2, pp.859-860, 2007.8 (in Japanese) 菅原貴之, 宮崎光生： RC2 次壁用スリットダンパーの開発, 日本建築 学会大会学術講演梗概集, B-2 分冊, pp.859-860, 2007.8

7) Shusaku Sumi, Takuya Yoshimura, Tomokazu Yoshioka: An Experimental Study on Non-Bearing Partial Wall of RC/SRC Condominium Using as Energy Dissipation Device Part1. A Lateral Loading Test of Full Scale RC Partial Wall, Summaries of Technical Papers of Annual Meeting, Architectural Institute of Japan, Structure IV, pp.443-444, 2014.9 (in Japanese)

角周作，吉村拓也，吉岡智和：RC 方立て壁の制振デバイス化に関する 実験的研究 その $1 \mathrm{RC}$ 方立て壁の水平加力実験, 日本建築学会大会 学術講演梗概集, 構造 IV, pp.443-444, 2014.9

8) Yusuke Maida, Hiroyasu Sakata, Nobuyuki Izumi, Toshio Maegawa:
Experimental Study on Damage Control Structure applying Damper to Exterior/Partition Fiat Walls in Reinforced Concrete Frames, Proceedings of the Japan Concrete Institute, Vol.38, No.2, pp.355-360, 2016.7 (in Japanese) 毎田悠承, 坂田弘安, 和泉信之, 前川利雄：鉄筋コンクリート骨組に おける方立壁へのダンパー適用による損傷制御構造に関する実験研究, コンクリート工学年次論文集, Vol.38, No.2, pp.355-360, 2016.7

9) Toshio Maegawa, Yusuke Maida, Hiroyasu Sakata, Nobuyuki Izumi, Makoto Hamada: Study on Effective Use of RC Partial Wall utilizing Energy Dissipation Device Part 4. Investigation of Structural Behavior of Steel Slit-dampers in RC Partial Wall, Summaries of Technical Papers of Annual Meeting, Architectural Institute of Japan, Structure IV, pp.641-642, 2017.8 (in Japanese)

前川利雄, 毎田悠承, 坂田弘安, 和泉信之, 濱田真：エネルギ吸収デ バイスを用いた鉄筋コンクリート造方立壁の有効活用に関する研究 その $4 \mathrm{RC}$ 造方立壁に取り付けた鋼製スリットダンパーの力学挙動の 検討，日本建築学会大会学術講演梗概集，構造 IV, pp.641-642, 2017.8

10) Akira Takaki, Teruaki Yamanishi, Hiroshi Tagawa: Structural performance of seesaw vibration control system with steel slit-dampers, Summaries of Technical Papers of Annual Meeting, Architectural Institute of Japan, Structure III, pp.1197-1198, 2014.9 (in Japanese)

高木明，田川浩，山西央朗：鋼製スリットダンパーを有するシーソー 制振システムの構造性能, 日本建築学会大会学術講演梗概集, 構造 III, pp.1197-1198, 2014.9

11) Akira Takaki, Teruaki Yamanishi, Hiroshi Tagawa: Hardening by means of geometrical nonlinearity for seesaw system with steel slit damper, Proceedings of Annual Meeting of Chugoku Chapter, Architectural Institute of Japan, Vol. 39, pp.261-264, 2016.3 (in Japanese)

高木明，山西央朗，田川浩：鋼製スリットダンパー部の幾何学的非線 形性に伴う硬化について, 日本建築学会中国支部研究報告集, 第39巻, pp.261-264, 2016.3

12) Architectural Institute of Japan: Stress Transferring Mechanism and Resistance Mechanism of Steel-Reinforced Concrete Joints, 2011.2 (in Japanese)

日本建築学会：鋼コンクリート構造接合部の応力伝達と抵抗機構, 2011.2

13) Architectural Institute of Japan, Standard for Structural Calculation of Reinforced Concrete Structures revised 2010, 2010.6 (in Japanese) 日本建築学会：鉄筋コンクリート構造計算規準・同解説 2010, 2010.6

14) Building Guidance Division, Housing Bureau, Ministry of Land, Infrastructure, Transport and Tourism et al. (editor): Commentary of Japanese Building Code for Structural Safety, 2007.8 (in Japanese) 国土交通省住宅局建築指導課ほか監修：2007 年版建築物の構造関係技 術基準解説書, 2007.8

15) Masanori Tani, Tomohisa Mukai, Masaya Ogura, Rafik Taleb, Susumu Kono: Full-scale Experiment on Non-structural R/C Walls Focused on Failure Modes and Damage Mitigation, Second European Conference on Earthquake Engineering and Seismology, ID 656, pp.1-12, 2014.8

16) Ken Kamachi, Masahiro Inayama, Masafumi Inoue, Naoto Ando: Design Method to Estimate the Load-Slip Characteristics of Bolted Joints with the Steel Side Plates, Journal of Structural and Construction Engineering (Transactions of AIJ), Vol.73, No.631, pp.1599-1606, 2008.9 (in Japanese) 蒲池健, 稲山正弘, 井上雅文, 安藤直人：鋼板添え板式ボル卜接合部 における荷重一すべり特性の評価法，日本建築学会構造系論文集，第 73 巻, 第 631 号, pp.1599-1606, 2008.9

17) Architectural Institute of Japan: Guidelines for Performance Evaluation of Earthquake Resistant Reinforced Concrete Buildings (Draft), 2004.1 (in Japanese)

日本建築学会：鉄筋コンクリート造建物の耐震性能評価指針（案）. 同解説, 2004.1

18) Masahiro Bunno, Kenji Nagayama, Masaki Maeda, Akira Tasai: An Evaluation of Residual Seismic Capacity of Reinforced Concrete Columns Based on Structural Damage, Proceedings of the Japan Concrete Institute, Vol.23, No.3, pp.259-264, 2001.7 (in Japanese)

文野正裕，永山憲二，前田匡樹，田才晃: $\mathrm{RC}$ 柱の損傷状態に基づく残余 耐震性能の評価，コンクリート工学年次論文集，Vol.23，No.3， pp.259-264, 2001.7 


\title{
EXPERIMENTAL STUDY ON THE EFFECTIVE USE OF LIGHTLY RC WALL PIERS UTILIZING STEEL ROD DAMPERS
}

\author{
Yusuke MAIDA*1, Takayoshi MORI ${ }^{* 2}$, Hiroyasu SAKATA*3, \\ Nobuyuki IZUMI ${ }^{* 4}$ and Toshio MAEGAWA ${ }^{* 5}$ \\ ${ }^{* 1}$ Researcher, Building Dept., National Institute for Land and Infrastructure Management, MLIT, Dr.Eng. \\ ${ }^{* 2}$ Former Grad. Student, Tokyo Institute of Technology, M.Eng. \\ ${ }^{*}$ Prof., Dept. of Arch. and Build. Eng., Tokyo Institute of Technology, Dr.Eng. \\ ${ }^{*}$ Prof., Graduate School of Eng., Chiba University, Dr.Eng. \\ ${ }^{* 5}$ Technical Division, Kumagai Gumi Co., Ltd., M.Eng.
}

Pilot tests were conducted on a reinforced concrete (RC) frame that had lightly RC wall piers with a steel slit damper for their effective use. In the pilot tests, when the damper was applied to the lightly RC wall piers, a damping effect was observed without adversely affecting the RC frame and the lightly RC wall piers. This showed the effectiveness of the proposed system. However, the damper force was not stabilized because of the damage to the connection between the lightly RC wall piers and the steel slit damper, the axial force acting on the lightly RC wall piers, etc. To solve these problems, a steel rod damper rationally applied to the lightly RC wall piers was used, and component tests of the lightly RC wall piers and subassemblage tests of the RC frame with lightly RC wall piers were conducted. Through these tests, the structural behavior was confirmed.

Component tests were conducted on four specimens using the steel rod damper proposed for application to the lightly $\mathrm{RC}$ wall piers as a parameter. As a result, the proposed steel rod damper became a stable restoring force without causing significant damage to the lightly RC wall piers. In addition, a method for evaluating the damper force was examined.

From the results of the component tests, the most rational and simply detailed steel rod damper was selected; the tests were conducted on the RC frame subassemblage with lightly RC wall piers. The parameters for the test specimens were different methods of fixing the steel rod damper to the lightly RC wall piers. There are two fixing methods: one with a joint in which the damper axis direction is unconstrained, and one with adhesion and fixing in the axial direction.

The test results of both specimens show that steel rod dampers start to dissipate energy at an early stage with story drift ratios much smaller than those at yielding RC frames. In the specimen in which the steel rod damper was fixed to the lightly RC wall piers, the stress was increased by the rope effect in the large deformation zone. By installing an axially unconstrained steel rod damper onto lightly RC wall piers designed considering the input shear force from the damper, it is possible to increase the damping effect without causing damage. The part with the largest steel rod damper curvature was not the concrete face but the position where it penetrated the concrete. 